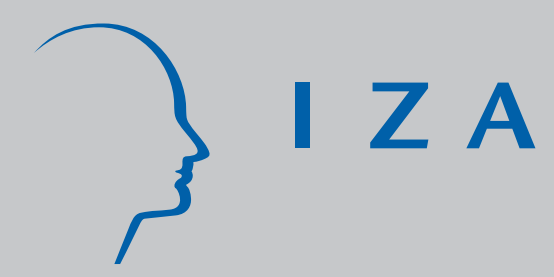

IZA DP No. 3202

From the Shortage of J obs to the Shortage of Skilled Workers: Labor Markets in the EU New Member States

J an Rutkowski

December 2007 


\title{
From the Shortage of Jobs to the Shortage of Skilled Workers: Labor Markets in the EU New Member States
}

\author{
Jan Rutkowski \\ World Bank \\ and IZA
}

\section{Discussion Paper No. 3202 \\ December 2007}

IZA

P.O. Box 7240

53072 Bonn

Germany

Phone: +49-228-3894-0

Fax: +49-228-3894-180

E-mail: iza@iza.org

\begin{abstract}
Any opinions expressed here are those of the author(s) and not those of the institute. Research disseminated by IZA may include views on policy, but the institute itself takes no institutional policy positions.
\end{abstract}

The Institute for the Study of Labor (IZA) in Bonn is a local and virtual international research center and a place of communication between science, politics and business. IZA is an independent nonprofit company supported by Deutsche Post World Net. The center is associated with the University of Bonn and offers a stimulating research environment through its research networks, research support, and visitors and doctoral programs. IZA engages in (i) original and internationally competitive research in all fields of labor economics, (ii) development of policy concepts, and (iii) dissemination of research results and concepts to the interested public.

IZA Discussion Papers often represent preliminary work and are circulated to encourage discussion. Citation of such a paper should account for its provisional character. A revised version may be available directly from the author. 


\section{ABSTRACT}

\section{From the Shortage of Jobs to the Shortage of Skilled Workers: Labor Markets in the EU New Member States}

Labor markets in the transition economies of Central and Eastern Europe underwent a dramatic transformation. Notably, this transformation took place within just a few years. Until the mid-2000s job opportunities were scarce and unemployment was high. But since then labor demand has picked up and unemployment has dropped substantially. In contrast to the earlier period of weak labor demand, it is now the supply side of the labor market that constrains job creation. These spectacular improvements can hardly be attributed to the greater labor market flexibility or to the more efficient matching of workers with jobs because no major reforms to labor market institutions were recently implemented in the region. Instead, the main cause was a strong increase in labor demand, as evidenced by the increase in the job vacancy rates and real wages. The surge in labor demand is likely to reflect successful enterprise restructuring supported by the improvements in the investment climate and access to global markets associated with the EU accession. For a long time enterprises in transition economies were improving competitiveness by shedding of redundant labor. Now they use productivity gains to invest, expand output and hire more workers. However, the emerging skills shortages may constrain firm growth. Thus the transition economies face a challenge of mobilizing effective labor supply. This requires improving labor supply incentives and investing in education. This paper documents the recent changes in labor market conditions in the transition economies, suggests tentative explanations, and finally suggests policies to address the emerging challenges.

JEL Classification: J21, J23, J63, J64, P23, O52

Keywords: $\quad$ transition economies, labor market, unemployment, skill shortages

Corresponding author:

Jan Rutkowski

World Bank

1818 H Street, N.W.

Washington, DC 20433

USA

E-mail: jrutkowski@worldbank.org 


\title{
From the Shortage Of J ObS to the ShORTAGe OF SkILLEd WORKerS
}

\author{
Labor Markets in the EU New Member States ${ }^{1}$
}

\author{
BY \\ J AN RUTKOWSKI ${ }^{2}$
}

\begin{abstract}
Unemployment has fallen substantially in virtually all EU8+2 countries since 2004 due to strong growth in labor demand. This labor demand growth has given rise to skill shortages and associated wage pressures, often amplified by out-migration. However, employment/working age population ratios are relatively low. In contrast to the earlier period of weak labor demand it is now the supply side of the labor market that constrains new job creation. Many persons of working age are economically inactive in EU8+2 either because they lack skills demanded by employers, or because of labor supply disincentives, such as early retirement benefits, high payroll taxes, or limited opportunities for flexible work arrangements. Hence the main challenge facing now EU8+2 is to mobilize labor supply to meet the demand. Addressing the emerging skills shortages is particularly important, because failure to do so will constrain to job creation and future economic growth. To increase the effective labor supply EU $8+2$ countries need to: (a) improve labor supply incentives through reforming the social security systems, (b) improve worker skills through reforming the educational systems; and (c) import labor with skills that are in short supply by opening labor markets to foreign workers. The weights assigned to each policy depend on the nature of the most binding constraint to labor supply, which vary across countries.
\end{abstract}

The objective of this study is to document the recent changes in labor market conditions in EU8+2, to suggest some tentative explanations for the observed trends and patterns, and to recommend policies to address the emerging challenges.

The study is divided into five sections. Section I presents recent labor market changes in EU8+2. Section II discusses the main factors behind the improvement in employment outcomes in EU8+2. Section III identifies reasons for still low employment rates in most EU8+2 countries. Section IV focuses on the causes of low employment rates among youth and older workers - the two groups among which the employment rate is particularly low. Section $V$ argues that skill shortages are an emerging labor market challenge in EU8. Section VI recommends policies to address labor and skills shortages.

\section{Marked improvement in Labor Market Conditions in EU8+2}

Until the early 2000s labor market outcomes were disappointing in virtually all EU8+2 countries. Unemployment was high - often in double digits - and the employment/ working age population ratio, at around 60 percent was low, not only in relation to the Lisbon target of 70 percent, but was also below the EU-15 average of about 65 percent. These unfavorable labor market outcomes persisted despite economic growth. In fact, many EU8+2 countries

\footnotetext{
${ }^{1}$ The paper focuses on a group of countries referred to as EU8+2, which comprises transition economies of Central and Eastern Europe that joined the EU in 2004 (Czech Republic, Estonia, Hungary, Latvia, Lithuania, Poland, Slovakia and Slovenia), and in 2007 (Bulgaria and Romania). Croatia, which is an EU accession country, is also covered.

${ }^{2}$ The paper originally appeared as Special Topic in the World Bank EU8+2 Regular Economic Report, September 2007. It draws on inputs provided by a team of World Bank economists in the region including Paulina Holda, Leszek Kąsek, Ewa Korczyc, Anton Marcincin, Ewa Skrok and Lars Sondergaard. Thomas Blatt-Laursen and Catalin Pauna provided helpful comments and suggestions.
} 
experienced periods of jobless growth, when the growth in output was not associated with the growth in employment. The low elasticity of employment to growth reflected the so-called "defensive" enterprise restructuring. Firms tried to become competitive by reducing costs and shedding redundant labor. The period saw substantial job reallocation. However, this was driven largely by high rates of job destruction rather than by high rates of job creation. The size of the "new" expanding sector was too small to absorb labor released in the "old" declining sector. ${ }^{3}$ Labor demand was thus low, which meant limited hiring by firms, and little opportunity for jobseekers to escape unemployment (World Bank 2005).

In addition, intensive enterprise restructuring and the attendant high rates of job reallocation led to high rates of frictional unemployment where workers were moving from old jobs in the declining sectors to new jobs in expanding sectors. These transitions from old to new jobs were difficult as the newly created jobs often had skill requirements and locations different from the old jobs. Many workers, especially older ones, who lost their jobs in the declining industries (for example, heavy industry, mining) and lacked the skills required in the expanding industries (mainly in the services sector) withdrew from the labor force. This was facilitated by the availability of early retirement schemes and other welfare benefits. In addition, many workers withdrew from the labor force discouraged by the scarcity of job opportunities and fruitless job search efforts. For example, in Poland in 2002 discouraged workers accounted for 18 percent of the all economically inactive. ${ }^{4}$ Consequently, the so-called "augmented unemployment rate", which takes into account both the unemployed and the discouraged workers, was substantially higher in EU8+2 countries than the standard unemployment rate. ${ }^{5}$

The scarcity of job opportunities which was the main factor behind the poor employment outcomes during the initial phase of labor market transition in the EU8+2 countries is no longer present. In the mid-2000s - which coincided with the EU accession of eight transition economies - labor demand picked up and since then jobs have become more plentiful. ${ }^{6}$ - The pace of job creation began to exceed that of job destruction, so employment is growing and unemployment falling. Growth in employment goes hand in hand with the growth in real wages (see section II below), underlying the net increase in labor demand as the main factor behind the improvement in labor market conditions. ${ }^{7}$

This growth in labor demand is the result of two factors. First is the strong economic growth ignited by, global market conditions and, inter alia, EU accession. Second is an increase in the labor content of growth. The latter is likely the result of successful enterprise restructuring which rendered EU8+2 firms more competitive, allowing them to invest and expand.

Chart 1 shows employment dynamics in EU8+2 countries from 1997 to 2006. The general pattern is that employment growth turns from negative before 2000 to roughly stable between 2001 and 2004 and then to positive since 2005 (Croatia, Hungary and Slovenia are exceptions). ${ }^{8}$ In a number of cases the acceleration of employment growth rates in the recent period is

\footnotetext{
${ }^{3}$ The "new" sector consists mainly of de novo private, usually small firms, in the expanding industries, largely in services; the "old" sector consists of state owned or privatized firms, usually larger ones, in the shrinking industries, such as heavy industry or mining (World Bank 2002).

${ }^{4}$ In the Labor Force Survey the discouraged workers are defined as those who are willing to work but are not actively seeking employment.

${ }^{5}$ For example, in Poland the augmented unemployment rate at 29 percent in 2002 was 9 percentage points higher than the standard unemployment rate.

${ }^{6}$ This overall positive picture may mask significant regional variation in job prospects. In rural areas and in small towns job opportunities are often still limited, which, given the relatively low internal labor mobility in EU8+2, contributes to unemployment, despite the overall strong increase in labor demand.

${ }^{7}$ Labor emigration after the EU accession, which represents a negative supply shock, has contributed to wage pressures.

${ }^{8}$ Deviations from the general pattern of employment evolution during the transition reflect differences among countries in the speed of enterprise restructuring, and in sensitivity to external demand shocks (e.g. the Russian crisis). For example, Hungary experienced a wave of mass lay-offs already at the beginning of the transition. In contrast, enterprise restructuring in Croatia has been relatively slow, not least because of strict employment protection legislation (Rutkowski 2003a).
} 
remarkable. The most spectacular turnaround occurred in the Baltic States, but also in Poland and Bulgaria. For example, in Estonia the annual rate of employment growth increased from 2.0 percent during 1997-2000 to 3.7 percent during 2005-2006; in Poland from roughly -1.0 during 1997 - 2004 to 2.8 during 2005-2006.

\section{Chart 1. Average annual employment growth}

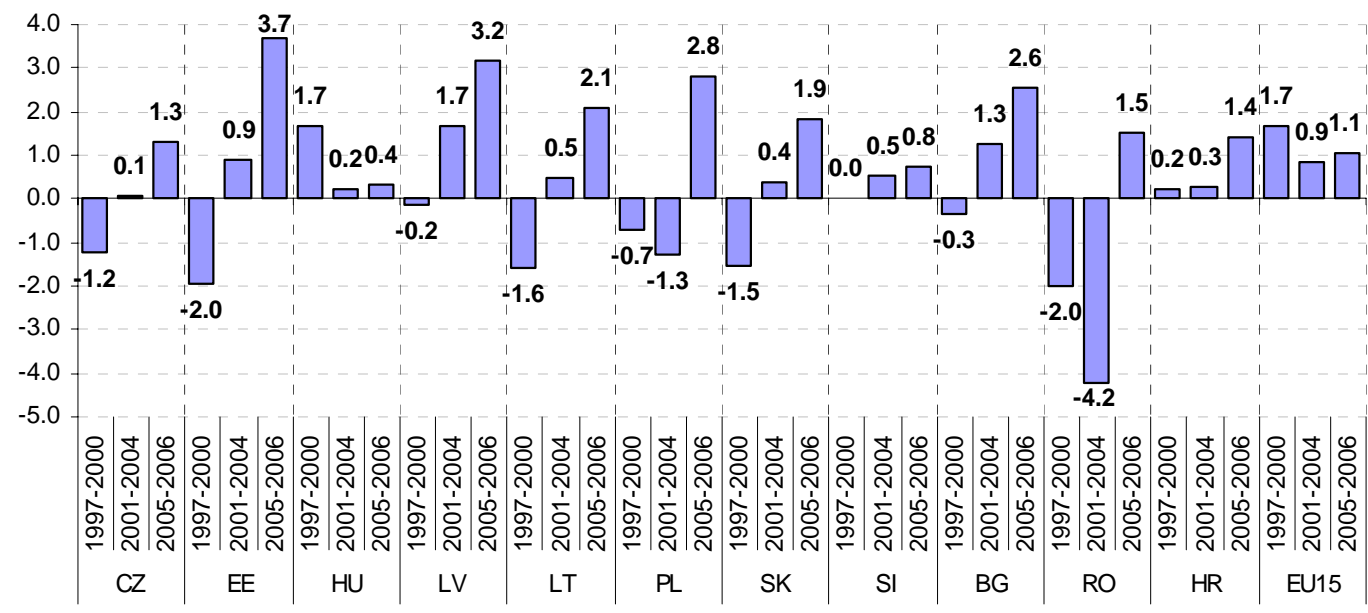

Source: Eurostat, Bank staff calculations

The increase in employment reflects the acceleration of economic growth in EU8+2 countries but, importantly, also an increase in the labor content of growth (Chart 2). Until 2004 the elasticity of employment with respect to output was in most EU8+2 countries either negative or negligible, meaning that output growth was not associated with employment growth. Starting with 2005 in all EU8+2 countries employment elasticities became positive and quite substantial, implying a significantly stronger effect of output growth on employment growth.

Chart 2. Employment elasticity of growth. Since 2003 employment has stared to respond to economic growth in EU8+2 and Croatia

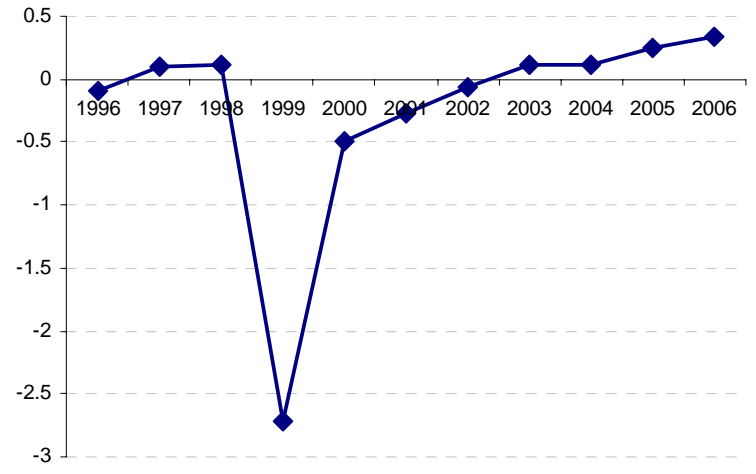

Source: Eurostat, Bank staff calculations
Table 1. Elasticity of employment to output, EU8+2, 1998-2006

\begin{tabular}{cccc}
\hline \hline & $1998-2000$ & 2001-2003 & 2004-2006 \\
\hline \hline CZ & -0.05 & -0.02 & 0.18 \\
EE & -3.78 & 0.16 & 0.22 \\
HU & 0.47 & 0.14 & 0.01 \\
LV & -0.32 & 0.25 & 0.23 \\
LT & 0.17 & 0.06 & 0.18 \\
PL & -0.35 & -1.42 & 0.50 \\
SK & -8.63 & 0.12 & 0.14 \\
SI & 0.14 & 0.13 & 0.14 \\
BG & -0.07 & 0.19 & 0.48 \\
RO & 1.16 & -0.26 & 0.15 \\
HR & 1.52 & -0.13 & 0.31 \\
& & &
\end{tabular}

Source: Eurostat, Bank staff calculations

Table 1 illustrates the almost uniform increase in employment elasticities across the EU8+2 and Croatia in recent years. For example, in Bulgaria, which is a representative case, employment elasticity to growth increased from roughly -0.1 during the late 1990 s to $0.2-0.5$ during the early to mid 2000s. Overall, in most countries the elasticity coefficient currently 
varies around $1 / 3$, ranging from nil in Hungary to 0.5 in Bulgaria and Poland. That is, 1 percent growth in output is associated with employment growth of $1 / 3$ percent. ${ }^{9}$ Put differently, employment growth contributes $1 / 3$ to output growth while the remaining $2 / 3$ is accounted for by labor productivity growth. ${ }^{10}$

Growth is most employment intensive in the construction and services sectors, while in industry, and especially in agriculture, employment elasticities tend to be close to zero or negative. Still in some countries - Bulgaria, Lithuania and Poland - output growth in industry in recent years is not only due to productivity growth but also to employment growth. The implication is that the key to future employment growth in EU8+2 and Croatia is the development of a modern services sector which in these countries remains smaller than in mature market economies. This does not mean that industry has no role to play in job creation, but that the role is likely to be secondary.

\section{Expectedly, the high rate of net job creation observed in EU8+2} and Croatia since the mid 2000s has led - with some lag - to the fall in the unemployment rate and a concomitant increase in the employment/population ratio. The fall in the unemployment rate in the mid-2000s has been spectacular (Chart 3). In the early 2000s the unemployment rate in region hovered around 15 percent (with the exception of the Czech Republic, Hungary, Romania and Slovenia). Currently, in most EU8+2 the unemployment rate is below 10 percent. The most dramatic drops in the unemployment rate occurred in

Chart 3. Change in unemployment rates 2000 2006 (15-64)

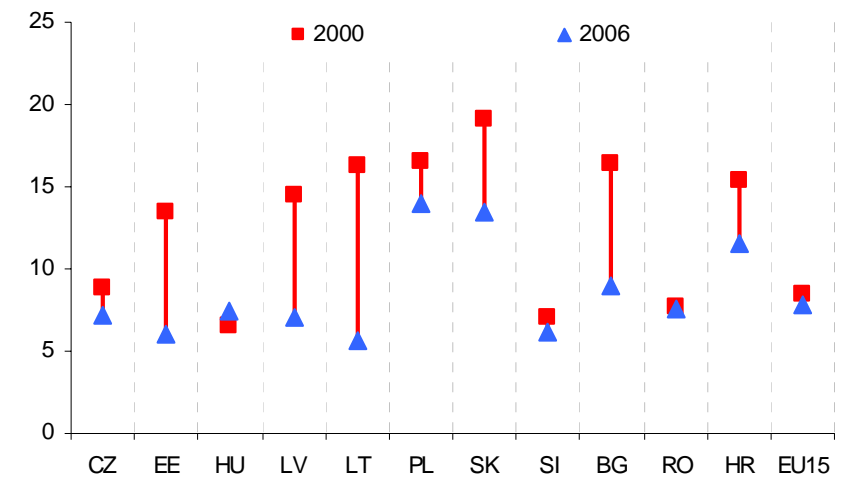

Source: Eurostat, Bank staff calculations

Notes: For HR data from 2002 the Baltic States, Bulgaria and Slovakia. For example, in Lithuania the unemployment rate fell by nearly 11 percentage points over 6 years. According to the most recent data, Poland is following this pattern with a reduction of the unemployment rate from about 20 percent in 2002 to some 10 percent in 2007. These developments mark an unprecedented change in labor market conditions across a large group of countries and within a short period of time. The substantial labor market slack, characteristic of the earlier stage of the transition has virtually disappeared and there are now signs of emerging labor shortages (see section $\mathrm{V}$ below).

9 The issue of causality is tricky here. On the one hand, it is employment growth that contributes to output growth (as in the production function). On the other, it is firms' intentions to increase output (in response to expected growth in product demand) that cause them to increase employment.

${ }^{10}$ This simple analysis is meant to depict the overall change in the labor content of growth that occurred along with the progress of the transition. It disregards the fact that EU8+2 and Croatia have followed different paths of transition (for example significant labor shedding occurred in Hungary and Poland much earlier than in Bulgaria and Romania). Accordingly, in a particular period EU $8+2$ and Croatia were at different stages of restructuring, making the elasticity figures not directly comparable. For this reason the above analysis should be regarded as only illustrative. 
Unemployment rates fell largely because many of the unemployed were able to find jobs thanks to the accelerated pace of job creation. Thus, the fall in unemployment led to an increase in the ratio of employment/working age population, i.e. to better utilization of labor resource ${ }^{11}$. Chart 4 shows the progress that EU $8+2$ countries have recently achieved in moving towards the Lisbon target of the 70 percent employment/ working age population ratio. Again, the Baltic States made the biggest strides. For example, in Latvia the employment ratio increased by nearly 9 percentage points from 2000 to 2006 and is now slightly above the EU15 average. Bulgaria also has made a substantial progress, although from a very low level so that a large gap still remains.

Some countries however have achieved little progress. These include Croatia, Hungary and Poland, where the employment/population ratio has moved very little and remains low. Romania stands out as the only country in the region where the employment/ population ratio fell during the 2000s. ${ }^{12}$ The dip was considerable (over 5 percentage points) and as a result Romania is now among the worst performers in terms of the utilization of labor resources.

\begin{abstract}
Although most countries in the region have achieved substantial progress in the utilization of their labor resources, there is no room for complacency. After all, in whole region the employment/ population ratio is still well below the Lisbon target, and in most it is below the EU15 average. And while the EU15 average can be useful reference point, one should bear in mind that labor market performance in many, especially continental, EU15 countries leaves much to be desired: unemployment rates are relatively high, and labor force participation is low. The employment rates in well performing labor markets, such as that of Denmark, Ireland, the Netherlands or the UK are close to or exceed the Lisbon target of 70 percent. Thus, there is still considerable space in virtually all EU8+2 economies to mobilize labor supply in order to better utilize labor resources and promote economic growth. We look at this issue in more detail in section III.
\end{abstract}

\title{
II. The Surge in Labor Demand is a Key Factor Behind the Recent Improvements in Employment Outcomes in EU8+2
}

What has caused the recent spectacular improvement in labor market conditions in the region? An obvious answer seems to be that the primary factor is the strong economic growth, associated with EU accession and a global economic upswing. But this can only be part of the story. We have already seen that economic growth does not necessarily translate into employment growth as virtually all the countries experienced periods of jobless growth. The more relevant question is why the elasticity of employment to output increased in EU8+2. There are four possible explanations for the recent fall in unemployment: (a) an increase in firm demand for labor associated with successful firm restructuring and the economic upswing,

\footnotetext{
${ }^{11}$ This is not an obvious effect. Unemployment can decrease because the unemployed withdraw from the labor force (as it happened for example in Hungary in the late 1990s). In such a case the fall in unemployment does not lead to the increase in the employment/ population ratio.

${ }^{12}$ This was associated with the decline in rural employment, while urban exhibited some upward trend. Up to the early 2000 s, agriculture acted as a shock absorber and an employer of last resort in Romania, including for workers released from the industry sector. After peaking in 2004 (at some $40 \%$ of total employment) agricultural employment has begun to decrease again in Romania.
} 
(b) enhanced labor market flexibility, (c) more effective matching of workers to jobs thanks to active labor market programs, and (d) out-migration of "excess" labor thanks to the opening of some EU15 labor markets. While the evidence is still tentative we conclude that the first hypothesis - a positive shock to labor demand-is the most plausible one.

\section{a) Firms' demand for labor}

A marked increase in vacancy rates points to the increase in labor demand as a primary factor behind the recent improvement in labor market conditions in EU8+2. The average job vacancy rate ${ }^{13}$ in the region, which is an indicator of the strength of labor demand, increased by almost 60 percent within the two last years alone (Chart 5). ${ }^{14}$ And the increase in vacancy rates was uniform across the EU $8+2$ with the exception of Bulgaria, where it remained stable over the last three years. The increase in vacancy rates was most pronounced in the Baltic

\section{Chart 5. Vacancy rates in EU8+2}

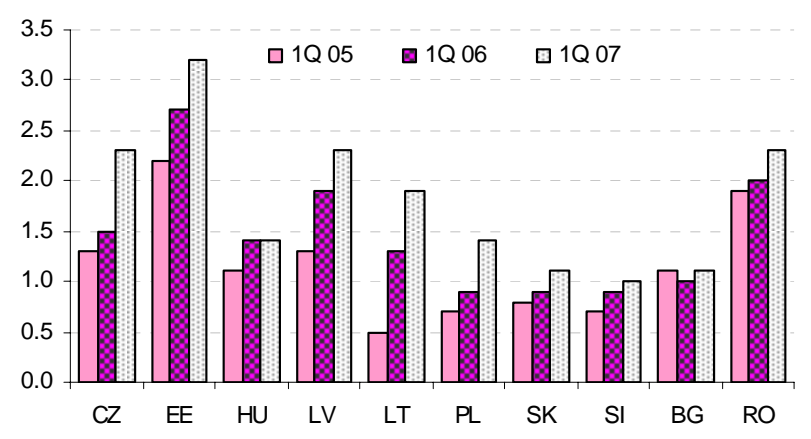

Source: Eurostat, Bank staff calculations.

Notes: Enterprises employing more than 10 workers.

States, in the Czech Republic and in Poland. For example, from 2005 to 2007 the vacancy rate more than tripled in Lithuania, doubled in Poland, and almost doubled in the Czech Republic and Latvia. These figures, and the earlier ones on employment growth, leave no doubt that virtually all countries experienced a surge in labor demand after the 2004.

\section{The wage growth that has accompanied employment growth is yet another sign of an increase in \\ Chart 6. Average annual wage growth in EU8+2+Croatia, 2000-2006} labor demand in the region (Chart 6). ${ }^{15}$ During the recent period (2003-2006) wage growth was strongest in the Baltic States, where the employment rates rose, and unemployment rates fell the most, and where they are currently the lowest in the region. Moreover, wage growth in the Baltic States accelerated compared to the early 2000s. Largescale out-migration (relative to the labor force) from the Baltic States reduced labor supply adding to the wage pressures.

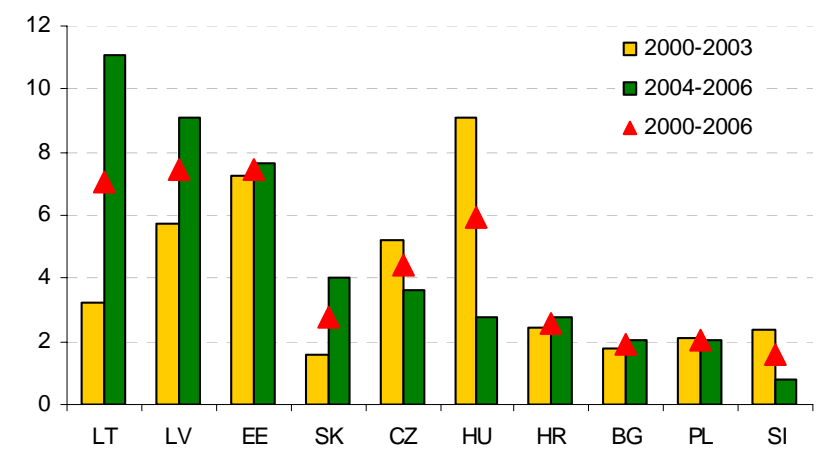

Source: CSOs, Bank staff calculations

An increase in product demand is the most likely reason EU8+2 firms are hiring more workers. While in the earlier period firms were able to meet the demand for their products by increasing productivity rather than by expanding employment it is most likely that the increase in the elasticity of employment to output is because firms moved from "defensive" to "strategic" restructuring. While "defensive" restructuring involves improving labor productivity and competitiveness through shedding of redundant labor, "strategic" restructuring, by contrast, is associated with using productivity gains to increase market share, expand output,

\footnotetext{
13 The vacancy rate is the ratio of job vacancies over the sum of occupied posts and vacancies (expressed as a percentage). Data comes from Eurostat.

${ }^{14}$ From the $1^{\text {st }}$ quarter of 2005 to the $1^{\text {st }}$ quarter of 2007.

${ }^{15}$ If, in contrast, employment growth was the result of the improvements in effective labor supply and in the matching function of the labor market then it would not be associated with wage growth.
} 
and consequently, hire more workers (World Bank 2005). Strong and robust export growth in EU8+2 since 2004 (at an annual rate of around 20 percent) supports the assertion that the countries reaped the benefits of the earlier restructuring efforts, become more productive, and can now successfully compete in the global market. It is worth emphasizing that that the transition from "defensive" to "strategic" firm restructuring was conditioned by investment climate reforms implemented in EU8+2, that encouraged firm creation and growth. ${ }^{16}$

\section{b) Labor Market Flexibility}

\section{All transition economies of CEE inherited strict employment protection legislation characteristic of the communist system. Although EU8+2 countries revised their labor codes to reduce employment protection, in most cases their labor markets are still highly regulated and hiring and firing costs are high. ${ }^{17}$ In fact, according to some indexes, labor markets in the region are not only more rigid than non-EU OECD countries, but also than EU15 countries (Chart 7, Chart 8). ${ }^{18}$}

But high and persistent unemployment at the earlier stage of the transition was not due to labor market rigidities. If it were then the rapid fall in the unemployment rate would have to have been preceded by farreaching labor market reforms and the reduction in firing and hiring costs. But it was not.

\section{Chart 8. Average rigidity of employment index in EU25}

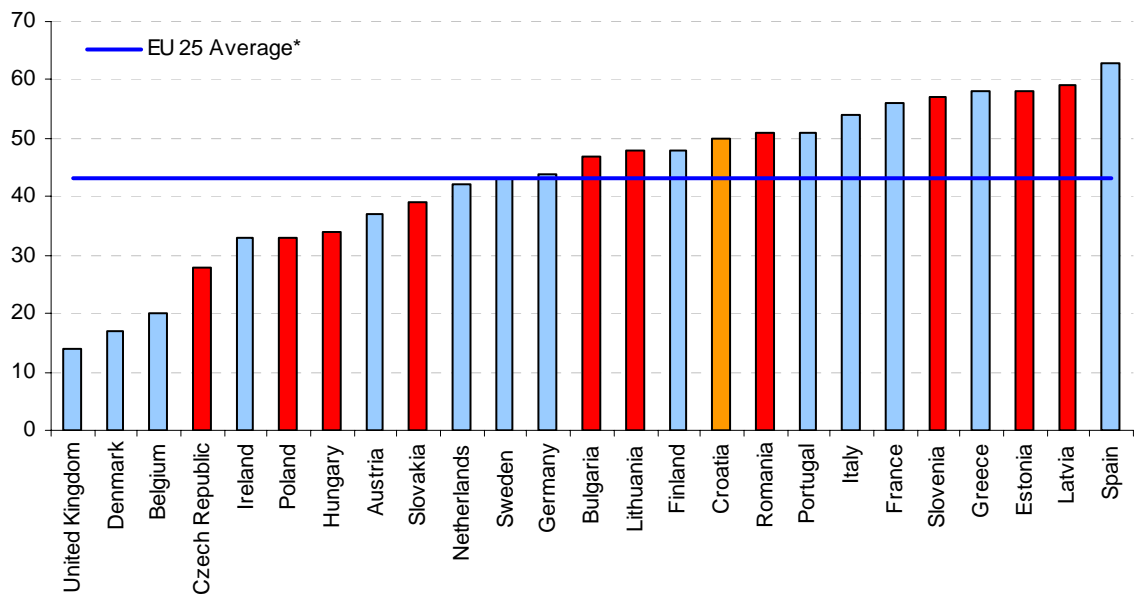

Source: World Bank Doing Business database 2006, Bank staff calculations

In most countries in the region there was no significant liberalization of employment protection legislation implemented during the 2000s (Box 1). Some countries (for example

\footnotetext{
${ }^{16}$ See World Bank annual Doing Business reports for information on investment climate reforms in EU8+2.

${ }^{17}$ Employment protection in some EU8+2 is strict on the books, but often not enforced, especially in small private firms, which provides for de facto labor market flexibility.

${ }^{18}$ This is telling because it is often claimed that labor markets in continental EU15 are "sclerotic", that is rigid and stagnant.
} 
Bulgaria, Croatia, Poland and Romania) did introduce reforms but they tended to be limited or partial, and mainly consisted of allowing greater use of fixed-term employment contracts. The Slovak Republic introduced a major reform in 2003, which significantly reduced firing costs, but it was largely reversed in 2007. All in all, employment protection legislation is still strict in EU8+2 and Croatia, and no less strict than it was during the period of high unemployment.

Box 1. Labor Market Reforms

According to the Doing Business report, labor market flexibility in EU $8+2$ has not improved much in recent years. Slovakia liberalized its Labor Code in 2003 by significantly reducing firing costs, but the ensuing revisions reversed many of the changes. Romania tightened its employment protection legislation in 2003. It then relaxed some of the restrictions, but the regulations remain relatively strict. It should be noted that some EU8 countries introduced labor market reforms before the EU accession. For instance Poland introduced labor market reforms providing greater employment flexibility in 2002. Efforts to improve the functioning of the labor market also included reductions in payroll taxes in Croatia, Romania and recently Poland. Below are some specific examples of recent labor market reforms in the region.

Romania substantially reduced the rigidity of employment as reflected in the improvement in the difficulty of hiring index (Chart B1). Significant amendments to the Labor Code in 2005 included an extension of the maximum length allowable for fixed term contracts from 18 to 72 months. However, there had been a tightening of employment protection in the Labor Code in 2003 (while allowing for partime employment and temporary work agreements).

At the same time the Czech Republic decided to introduce restrictions on the duration of fixed term contracts- no limit which existed before was replaced by a maximum duration of 24 months, with no possibility of renewal.

\section{Chart B1. Rigidity of Employment Index}

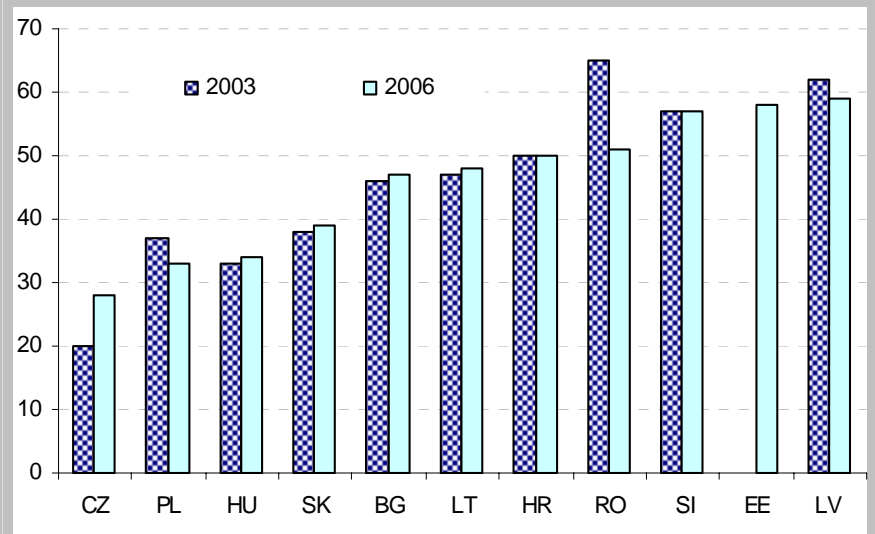

Source: : World Bank Doing Business database 2006, Bank staff calculations

Note: The index is available only since 2003. Thus it is not possible to show the impact of reforms that were introduced in or before 2003. EE: 2004 instead of 2003

Latvia will most probably improve its standing in the next Doing Business Report, as the country has recently amended its Labor Code and increased the maximum duration of fixed-term contracts from 2 to 3 years.

Slovakia amended its Labor Code in May 2003 and introduced "the most far-reaching changes" ${ }^{19}$; the least rigid regulation of hiring, which placed the country next to Singapore and United States. The new Labor Code increased the working week to 48 hours (with overtime), enabled flexible part-time arrangements; introduced an allowance for indefinite repetition of fixed term contracts; a cut in severance pay; and a considerable easing of the conditions under which workers can be dismissed. The code also weakened the powers of the trade unions and worker councils.

However, the $\mathbf{2 0 0 7}$ revisions to the Slovak Labor Code are regarded as a step backward. Amendments result in lower flexibility of labor relations and hence higher labor costs. The new regulations reversed positive changes from 2003: they give more power to the unions, limit overtime, toughen conditions of fixed-term employment contract and limit the use of trial periods before signing a permanent-status contract with the employee.

Poland recently attempted to improve labor market functioning by reducing payroll taxes. In J une 2007

\footnotetext{
${ }^{19}$ WB (2005). Doing Business in 2005, p. 26
} 
Polish parliament adopted a bill which cut the disability pension contribution rate by $3 \mathrm{pp}$. (to $10 \%$ of the wage). Next year a further $4 \mathrm{pp}$. cut is planned.

Similarly, labor market rigidity is unlikely to have been the main factor behind poor labor market outcomes at the earlier stage of the transition. Instead, the high unemployment at that stage was a consequence of intensive job reallocation and the relatively small size of the "new" sector of the economy. This does not mean that labor market flexibility is unimportant. It is. Many employers in the region complain about stringent labor market regulations. On average, one firm in ten sees them as a severe obstacle to firm operation and growth, but in some countries (Estonia, Poland, Czech Republic and Romania) this proportion is considerably higher reaching as much as 18 percent (Chart 9). ${ }^{20}$ Labor regulations may hinder labor market performance in EU8+2. However, the marked improvement in labor market outcomes has been achieved in the region without significant changes to employment protection legislation and hiring and firing costs are not so high, as to prevent firms from successful restructuring and firing and hiring workers in response to changing labor and product market conditions.

\section{Chart 9. Percentage of firms reporting labor regulations as a major obstacle to firm activity}

Many firms in EU8+2 and Croatia see labor market regulations as a major obstacle to firm activity

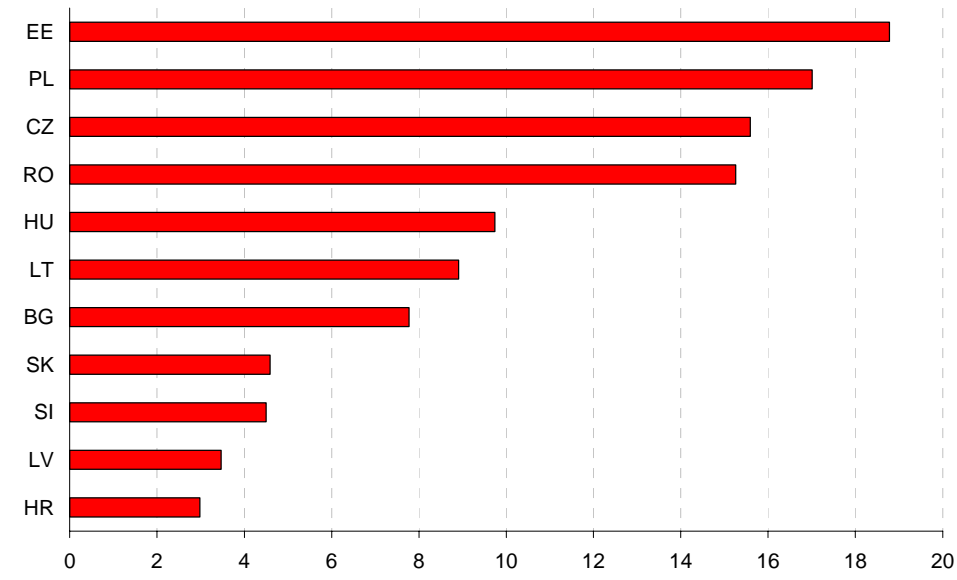

Source: EBRD-World Bank BEEPS 2005, Bank staff calculations

\section{c) Active Labor Market Programs}

It is not likely that labor market outcomes improved due to better matching of workers with jobs thanks to labor supply measures, such as job search assistance, training, and other activation programs provided by public employment services. Evaluation studies done in EU8+2 up to the early 2000s showed that the net impact of active labor market programs is limited (Betcherman 2004, Rutkowski 2004). ${ }^{21}$ For example, as a rule no more than 10 percent of the unemployed who received training found jobs thanks to program participation. Wage subsidies tend to have still lower impact. And public works do little to improve the labor market prospects of the unemployed. There is no evidence that these programs have become more effective in recent years. And spending on those programs (relative to GDP) is relatively

\footnotetext{
${ }^{20}$ This subjective perception of labor regulations by employers is not necessarily correlated with objective indices of labor market rigidity. First, subjective assessment of labor regulations is done relative to other obstacles to firm activity. Second, subjective assessment takes into account enforcement and thus the actual "bite" of the regulations, rather than what is on the books.

${ }^{21}$ A similar conclusion is reached by a recent thorough econometric study for 20 OECD countries (Boone and van Ours 2004). Specifically, the authors find that public employment services seem able to reduce the unemployment rate but do not affect the employment/population ratio. Subsidized jobs do not seem to have any effect on labor market outcomes. Only training seems to have some impact on both the unemployment rate and the employment/population ratio.
} 
low in EU8+2 (0.20 percent of GDP against 0.55 percent in EU15, see also Chart 10). But most importantly, these programs generally do not create new jobs, but instead tend to redistribute existing jobs: program participants often get employed at the expense of other job seekers. ${ }^{22}$ They may thus lower the unemployment rate by shortening the duration of unemployment, rather than through increasing employment. This means that they cannot account for the recent sharp increase in the number of jobs and job openings, which was the primary cause of the fall in unemployment.

\section{Chart 10. Spending on ALMP (\% of GDP), 2005}

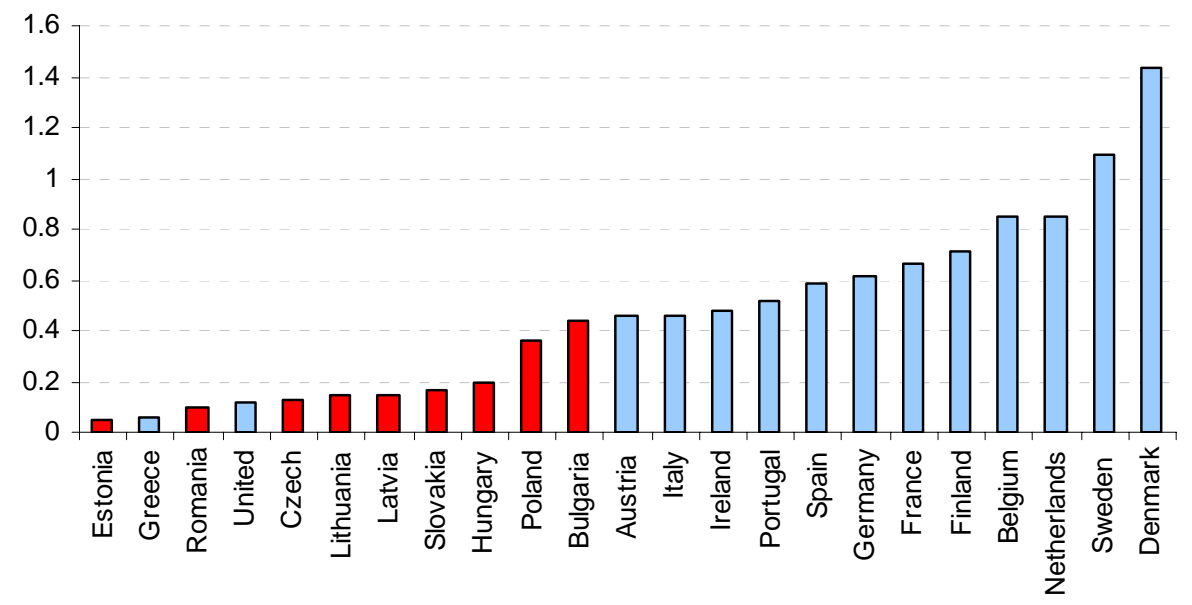

Source: Eurostat, Bank staff calculations

\section{d) Labor Migration ${ }^{23}$}

For the EU accession countries, opening the EU labor markets to migration was commonly seen as a means of relieving existing labor market tensions and reducing the excess supply of labor. Accordingly, the fall in the unemployment in the wake of EU accession was commonly attributed to the ensuing large labor migration flows from the new to the old EU members. ${ }^{24}$ These flows were particularly large (as a proportion of the domestic labor force) in the case of the Baltic States, Poland and Slovakia, that is, countries where unemployment has fallen the most. It thus seemed all natural to link those two phenomena. There is undoubtedly some truth to it: out-migration does reduce the number of workers relative to the number of jobs, and apparently makes it easier for the remaining workers to find a job. ${ }^{25}$

But out-migration can be only part of the story. While it can explain the fall in unemployment, it obviously cannot explain the concomitant rise in employment that occurred in EU $8+2$ countries. And the marked increase in the number of available jobs was likely to contribute more to the fall in unemployment than labor out-migration. ${ }^{26}$ Certainly, many of the unemployed must have benefited from better job opportunities at home, and not only from job opportunities abroad. What labor out-migration actually did is contribute to skill shortages and associated wage pressures in most sending countries - an issue that is discussed below.

\footnotetext{
${ }^{22}$ This is justified, if programs are targeted at disadvantaged worker groups, such as youth, long-term unemployed, persons with disabilities, ethnic minorities, etc.

${ }_{23}^{23}$ Labor migration was a special topic in a previous EU8+2 report (World Bank 2006).

${ }^{24}$ It should be mentioned that in some EU8+2 courtiers (Bulgaria, Poland and Romania) labor migration to Western Europe started well before the EU accession.

${ }^{25}$ In reality the situation may be more complicated. If the migrants are mainly those who were employed (or who were likely to be employed) then migration may actually raise, not lower, the unemployment rate.

Hence, the effect of out-migration on unemployment cannot be determined a priori but is an empirical issue.

${ }^{26}$ For example, in Poland employment increased by 920 thousand from 2004 to 2006, while unemployment decreased by 880 thousand.
} 
To summarize, the primary cause of the spectacular improvement in labor market conditions that has occurred in the region since the mid 2000s was a sharp increase in labor demand that manifested itself in the growth in employment, job vacancies and wages. This growth in labor demand reflected in turn successful enterprise restructuring, which enabled EU8+2 firms to grow and successfully compete on global markets. Undoubtedly, EU accession and the opening of EU product markets was a key factor in this respect. Other potential factors: improvements in the workings of the labor markets, active labor market programs, and labor out-migration played negligible or secondary role.

\section{Labor Remains Underutilized in the EU8+2}

Despite the recent improvements, employment outcomes are still weak in the region. While the unemployment rate has declined substantially, the employment/working age population ratio remains relatively low. Participation rates are especially low among younger and older workers. Moreover, the incidence of long-term unemployment - which is the most socially costly form of unemployment - is still high. Finally, in some countries a large fraction of the workforce is still employed in low-productivity agriculture.

Table 2 shows that the employment/working age population ratio - which is a summary measure of the utilization of labor resources - remains low in EU8+2, significantly lower than in EU15, and well below the Lisbon target of $\mathbf{7 0}$ percent. There is thus a considerable room for improvement. Roughly speaking, an increase the employment/population ratio by some 8 percentage points is needed to reach the "full employment" target.

Table 2. Selected LM Indicators in EU8+2, Croatia and EU15 by age, 2006

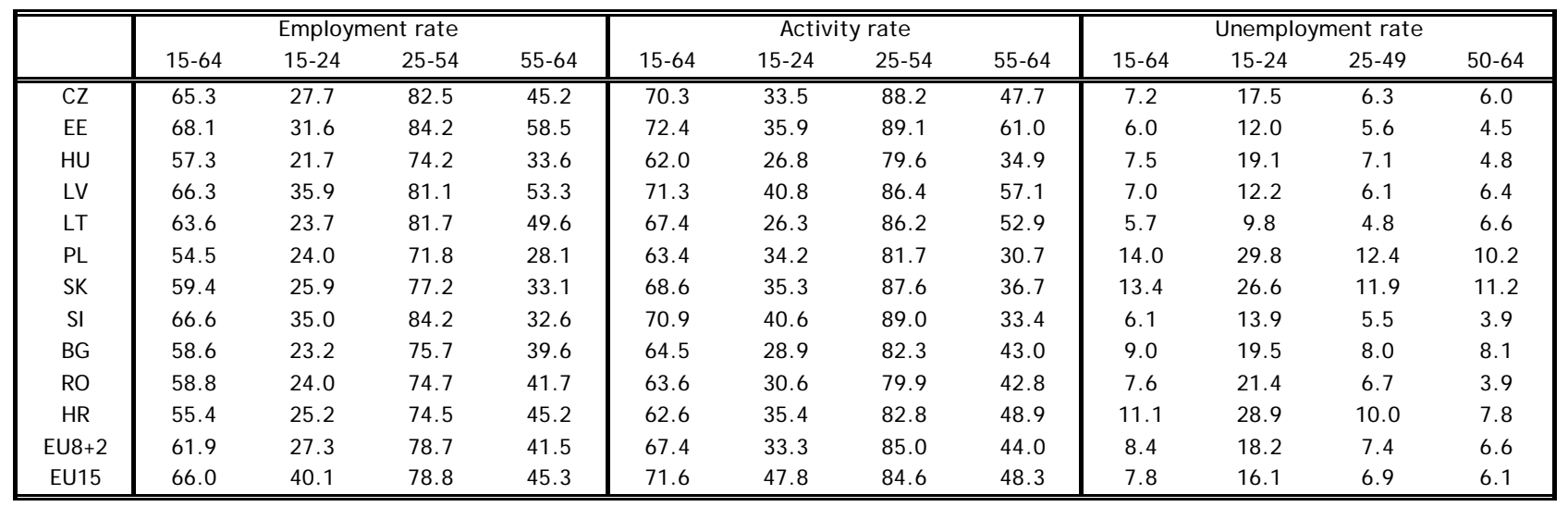

Source: Eurostat, CSOs.

The employment/population ratio in the region is particularly low among young and older workers. For the prime age workers $\left(25\right.$ - 54) there is no difference in employment rate ${ }^{27}$ between new and old EU member countries. The youth employment rate is particularly low in EU8+2: on average 27 percent, compared with 40 percent in the EU15. The difference for older workers less pronounced: 42 percent against 45 percent. This is not a reason for complacency however, as the EU15 average, which involves substantial variation across countries, is not a good benchmark. Many EU15 countries face considerable problems regarding the sustainability of their generous social security systems. In most successful EU15 economies, such as the Nordic countries (Denmark, Norway and Sweden) and the UK, the employment rate among older workers ranges from 60 to 70 percent. Thus, if one uses the 60 percent employment rate as a target, then there is almost 20 percentage point employment gap for this age group in EU8+2.

\footnotetext{
${ }^{27}$ Throughout the text we use the term "employment rate" as short for "employment/ working age population ratio". In some other sources, the employment rate is defined as the ratio of employment to the labor force.
} 
The youth employment rate is uniformly low in the region, ranging from 20 to 30 percent. The range of variation of the older worker employment rate is much wider: from 28 percent in Poland, to 45 percent in the Czech Republic, to 59 percent in Estonia. Clearly some countries face a bigger challenge in increasing the employment rate among older workers than others. ${ }^{28}$

The high incidence of long-term unemployment is another (in addition to low labor force participation rates) symptom of problems with effective labor supply. Under conditions of strong labor demand, the long-term unemployed are largely workers who lack employability or job readiness skills. Their problem is not lack of available jobs, it is that they lack skills (or incentives) necessary to take available jobs. The share of long term unemployment is 53 percent in EU8+2 and Croatia compared with 42 in EU15 (2006 data). But in well-performing labor markets (for example in Denmark, Ireland, UK), the long-term unemployed account for less than one-third of total unemployment. Thus the high incidence of long-term unemployment poses a serious social and economic problem in EU8+2+Croatia (Chart 11).

\section{Chart 11. Share of Iong-term unemployment in total unemployment, 2006}

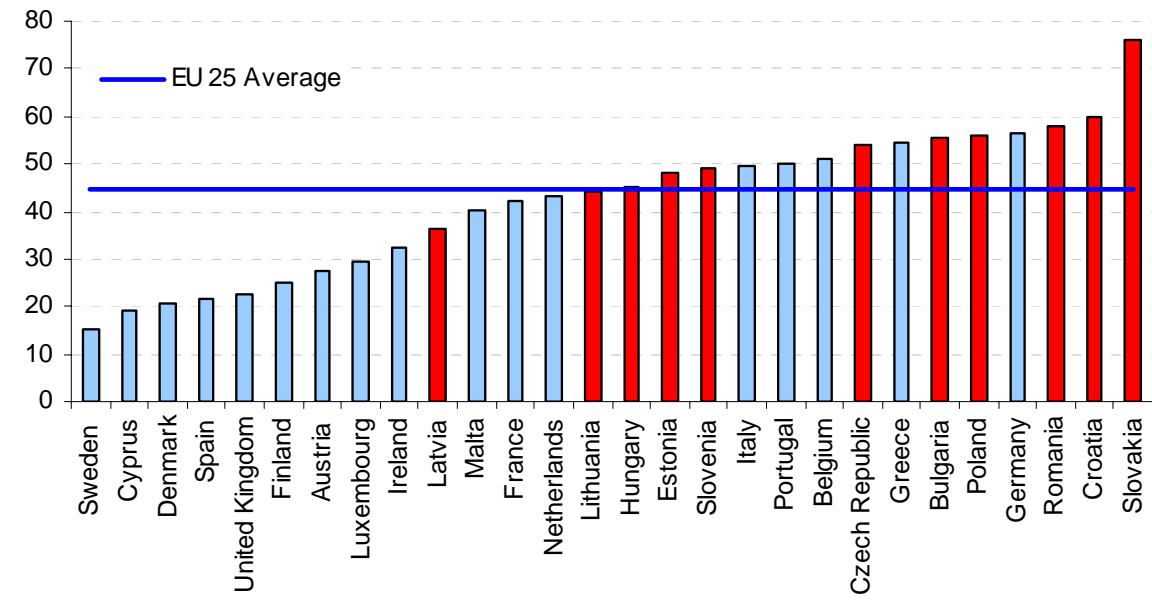

Source: Eurostat, Bank staff calculations

Notes: Long-term unemployment = unemployment lasting more than 12 months

The problem of long-term unemployment is pervasive in virtually all countries in the region, but is particularly pronounced in Slovakia, Croatia, Romania, Poland and Bulgaria (Chart 11). Slovakia is an extreme case: three out of four unemployed are jobless for more than one year. ${ }^{29}$ But in other countries the situation is not much better: the share of long-term unemployment ranges from 40 to 60 percent (Latvia being an exception). How to bring this large group of marginalized workers back to the jobs market poses a considerable policy challenge.

Less educated and older workers are disproportionately represented among the long-term unemployed in EU8+2 and Croatia (which is a typical pattern in OECD countries). For example, in Poland workers with less than secondary education account for as much as 60 percent of the long-term unemployed, but only 46 percent of the short-term unemployed and 40 percent of the employed. ${ }^{30}$ Similarly, older workers (men aged 50-59) represent 65 percent of the long-term unemployed, only 16 percent of the short-term unemployed and 13 percent of the employed. Apparently, long-term unemployment is strongly associated with poor or obsolete skills. This implies that unemployment in EU8+2 has a strong structural component

\footnotetext{
${ }^{28}$ Increasing the employment rate among older workers is imperative given the fast aging population in EU $8+2$ and increasing old age dependency ratios with attendant pressures on the fiscal sustainability of social security systems.

${ }^{29}$ The specificity of Slovakia may be due to the high incidence of long-term unemployment among the large Roma minority.

${ }^{30}$ The long-term unemployed are those unemployed for more than 12 months; the short-term unemployed are those unemployed for no more than 6 months.
} 
that will persist even with further increases in labor demand. The only chance for the longterm unemployed to find a job is to improve their skills.

The share of long-term unemployment tends to decrease along with the decrease in the unemployment rate. As jobs become more plentiful and labor turnover increases, the pool of unemployment becomes more fluid. Surprisingly, there are a few notable exceptions to this pattern: Poland, Slovakia and Romania, where the share of long term unemployed actually increased despite the improvement in overall labor market conditions, most likely because they lacked skills necessary to take the newly created jobs. ${ }^{31}$

\section{The persistently high unemployment rates among less- educated workers are further indication of the increasingly structural nature of unemployment in EU8+2 countries. Chart 12 shows that unemployment rates among less educated workers are still high in most EU8-2 countries, and substantially higher than among better educated workers (Romania and Slovenia are exceptions). Hence less educated workers benefit little from job growth.}

In some countries, a large proportion of the workforce in the region is still employed in agriculture, which is another sign of the underutilization of labor. This is

\section{Chart 12. Unemployment rates by educational} attainment, 2006

Unemployment is strongly associated with low educational attainment in EU8+2

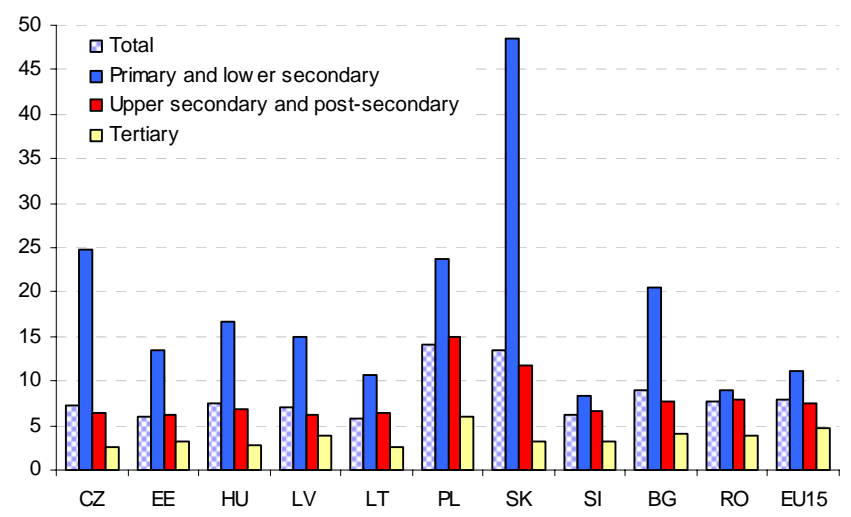

Notes: for SK unemployment rate is much higher for primary graduates (ca. 50percent) than lower secondary (ca. 15 percent) Source: Eurostat, Bank staff calculations.

particularly the case in Bulgaria, Poland and Romania, where agricultural employment accounts for from 20 to nearly 30 percent of total employment (Chart 13). Rural labor tends to be underutilized because agricultural employment in many EU8+2 countries is of low-productivity. Many workers produce little value added (which is a form of hidden unemployment). This implies that there is potential for increasing labor supply by accelerating agricultural restructuring. However, this is difficult because many of those employed in agriculture have low educational attainment and lack skills required in the expanding industries.

\section{Chart 13. Share of employment by sector, 2006}

Agricultural employment is still substantial in a number of EU8+2 countries

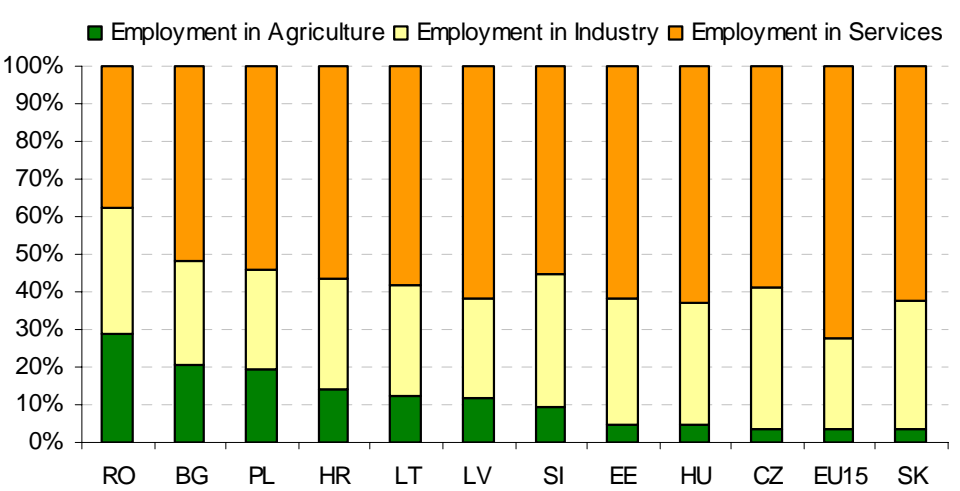

Source: Eurostat, CSOs, EC, Bank staff calculations

Notes: Ro data for 2004.

Retraining is costly and may play only a limited role. Poorly developed housing markets present another important obstacle to mobilizing the supply of workers from rural areas.

\footnotetext{
${ }^{31}$ The absolute number of long-term unemployed did fell in those countries with the improvement in job opportunities; however, it fell slower than that of short-term unemployed, leading to an increase in long term unemployment as a share of total unemployment.
} 
To sum up, labor in EU8+2 countries is underutilized despite the surge in labor demand. It is the labor supply side that has become a constraint. Labor force participation is low, especially among the young and older workers. Furthermore, the unemployed, most of whom are long term unemployed often lack skills that would allow them to take newly created jobs. Skills are also likely to be a constraint to mobility in the case of those employed in agriculture, where hidden unemployment looms large. The big policy challenge is thus to mobilize labor supply so as to meet labor demand. To do so one needs to understand the reasons why so many workers in the EU8+2 countries prefer to be out of the labor force. We turn to this issue in the next section.

\section{Substantial Room to Increase Labor Supply to Meet the Demand}

Few young and older workers are employed in EU8+2 countries, which is the main factor behind the low employment/population ratio in the region. The youth employment rate is low because young people in EU8+2 tend to stay longer in education than their EU15 counterparts, and they are less likely to combine education with work. Young workers may also suffer from strict employment protection regulations, which discourage employers from hiring inexperienced workers whose productivity is uncertain. The older worker employment rate is low due to labor supply disincentives created by the social security system, especially by early retirement and disability schemes. In addition, the high tax wedge on labor, characteristic of EU8+2 countries, is likely to discourage labor supply of and labor demand for both young and older workers (OECD 2006, Rutkowski and Walewski 2007).

\section{Young Workers}

Chart 14 shows that the proportion of early school leavers in EU8+2 is much lower than in EU15. Most EU8+2 countries are below the EU25 average share of early school leavers of 15 percent. For example, in the UK, France or Germany the proportion of early school leavers is almost twice as high as in the Czech Republic, Poland or Slovakia. This means that that the pool of young workers able to work full time is on average smaller than in EU15 because of their longer involvement in education. To the extent that the low youth employment rate in EU $8+2$ reflects the impact of this factor, it should be not viewed negatively.

\section{Chart 14. Early school leavers as a percentage of all youth, 2006}

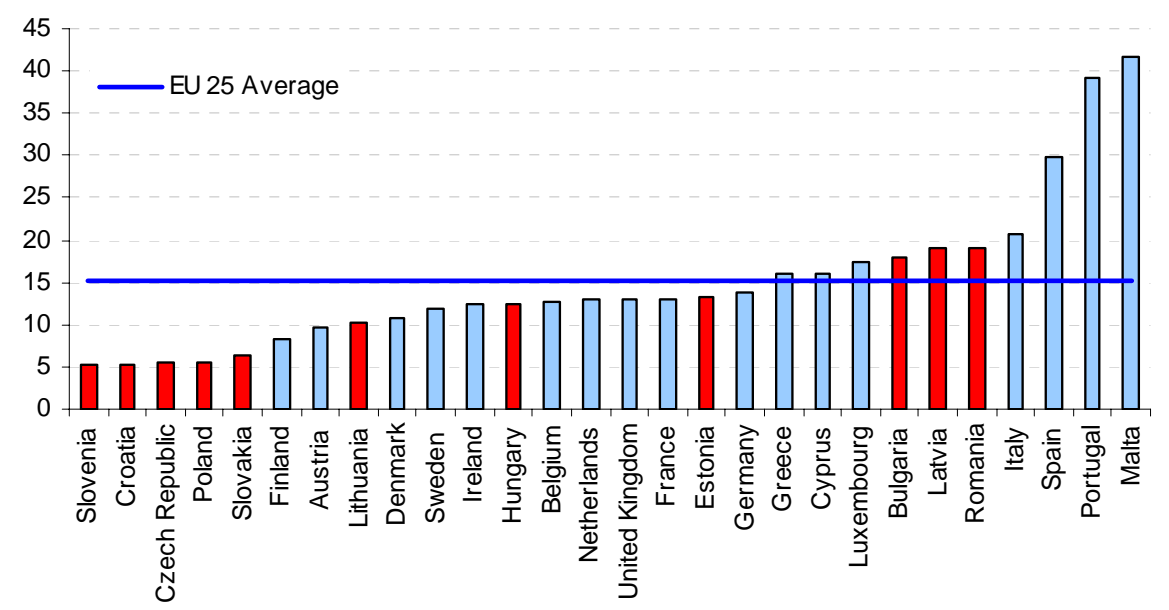

Source: Eurostat, Bank staff calculations

Notes: Percentage of the population aged 18-24 with at most lower secondary education and not in further education or training

At the same time, young people in EU8+2 are less likely than their EU15 counterparts to combine education with work. Chart 15 demonstrates that the share of youth in part-time employment is dramatically lower than in EU15. In few countries does youth account for more than 10 percent of part-time employment (the exceptions being Slovenia, Poland, Estonia and 
Romania), which is still well below the EU25 average of 27 percent. Tellingly, the share of youth in part time employment is the highest in those countries where the youth employment rate is particularly high: the Netherlands, Denmark, Sweden and the UK. This positive correlation between the youth employment rate and the incidence of part-time employment among youth suggests that promoting flexible work arrangements, including part-time work, is one way to bring youth into the workforce.

\section{Chart 15. Share of 15-24 in part-time employment, 2006}

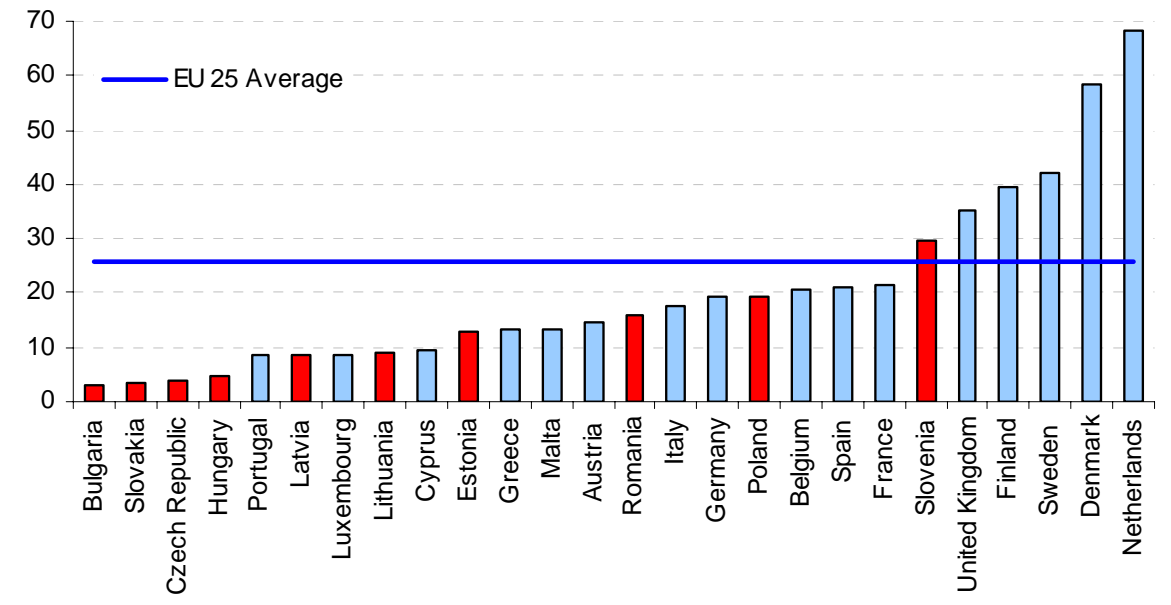

Source: Eurostat, Bank staff calculations

Youth employment in EU $8+2$ is also
likely to be discouraged by the high
rates of labor taxation. The so called rates of labor taxation. The so called
"tax wedge" is high in EU8+2, especially given the region's income level (Rutkowski and Walewski 2007). 3233 High labor taxes discourage both labor supply, through lowering the take-home pay, and labor demand, by raising the labor costs. The negative employment effect is particularly strong in the case of youth because of relatively high elasticity of both demand and supply (OECD 2006). Chart 16 illustrates the negative relationship between the tax wedge on labor and youth employment rate. It EU $8+2$ countries are clearly in the high tax wedge-low youth employment rate cluster.

\section{Chart 16. Tax wedge and employment rate among youth 15-24, EEA, 2005, \%}

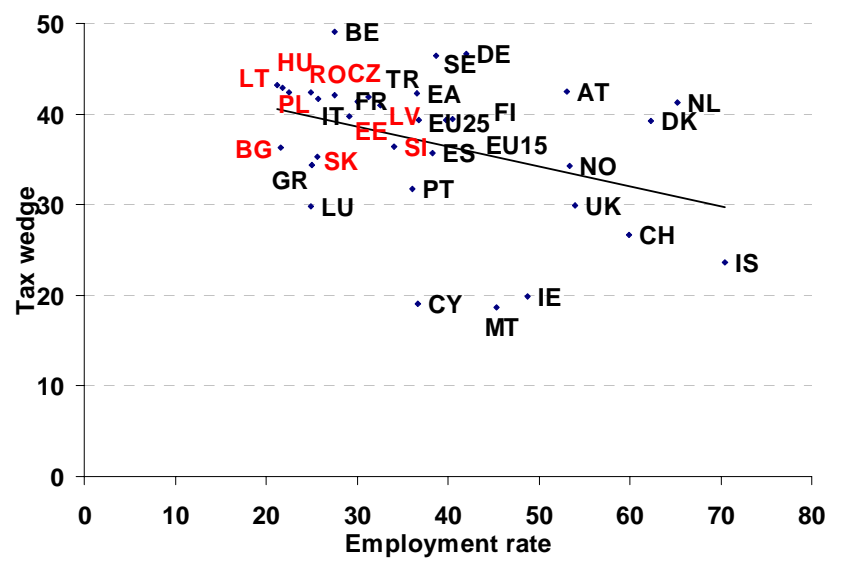

Source: Eurostat, Bank staff calculations

\footnotetext{
${ }^{32}$ Tax wedge is the difference between total labor cost to the employer and the net take-home pay of the employee, expressed as a percentage of the total labor cost.

${ }^{33}$ The disemployment effect of the tax wedge is stronger the higher is the elasticity of supply of and demand for a given type of labor. In addition, in the presence of a binding minimum wage, the effect is stronger for low paid workers, as employers are not able to shift the burden of the tax on employees due to the wage floor. Young workers meet all these conditions. Their labor supply is more elastic than that of prime-age workers, as does labor demand (which is generally more elastic in the case of less skilled/experienced labor). And youth, who lack labor market experience, on average earn less than prime age workers. Accordingly, the high tax wedge on labor hits young workers disproportionately hard (OECD 2006, Rutkowski and Walewski 2007).
} 
Finally, youth employment may be affected by minimum wages. Admittedly, in most cases the minimum/average wage ratio is below 40 percent in EU8+2 (Bulgaria and Slovakia being exceptions) and thus is not particularly high and generally lower than in EU15 countries (Chart 17). Still it may prevent young, inexperienced and less skilled workers from getting employment, especially in poorer regions, where the "going" wage rate is often well below the national average (Rutkowski 2003b). ${ }^{34}$ Studies for other countries find a significant but a relatively small effect of the minimum wage on youth employment (Neumark and Wascher 2007). If so, then minimum wage regulations cannot account for the large difference in youth employment rates between EU8+2 and EU15. Still, minimum wages may contribute to relatively poor employment prospects for less skilled youth in the region.

\section{Chart 17. Minimum wage to average wage ratio, 2005}

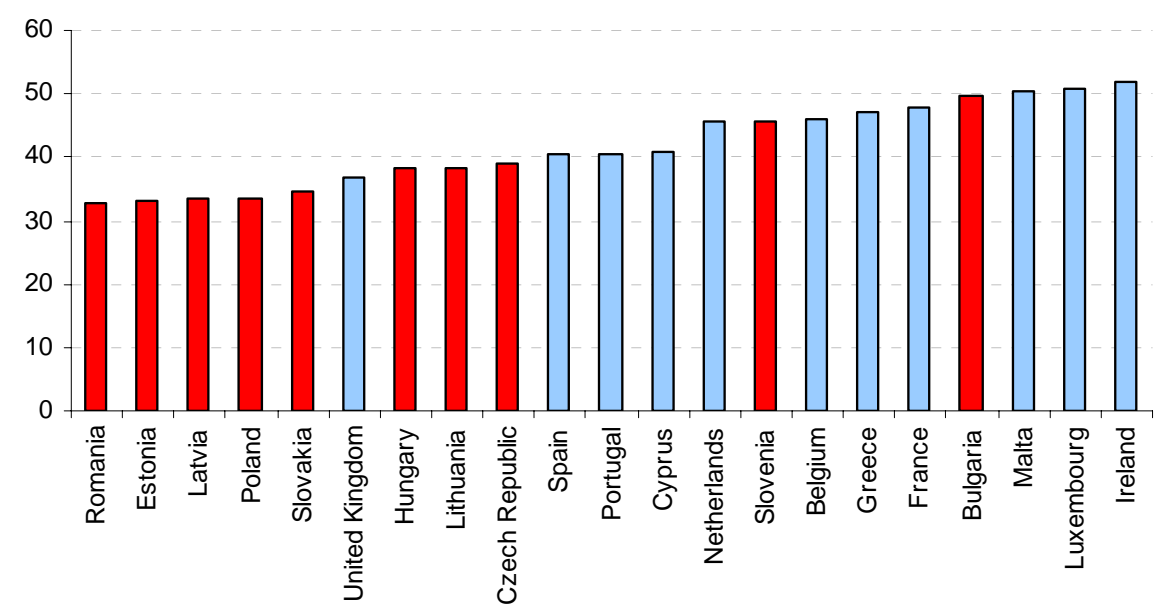

Source: Eurostat; Bank staff calculations

Notes: data for BE-2002, FR-2003, GR and CY- 2004

\section{Older Workers}

The low employment rate among older workers in the region is strongly affected by the design of social security systems. Many people of working age (55-64) are not employed because of the low statutory retirement age, and ample opportunities for early retirement. As a result, the average retirement age is significantly lower than the statutory retirement age. In addition, many older workers take advantage of the often lax rules governing the eligibility to disability pensions and use them as a substitute for retirement pension or unemployment benefits.

The statutory retirement age for men in EU8+2 is in the 62-63 range with Poland, where it is 65 years, being an exception. This is below the 65-67 range that is increasingly being adopted in EU15. However, the age at which men actually withdraw from the labor force into retirement in most cases is well below the official age. The average of median retirement ages for men in EU8+2 and Croatia is 60.9; thus the bulk of men retire when they are still of working age. ${ }^{35}$ For comparison, in countries such as Denmark, Ireland, the Sweden and UK the median male workers retire at the age of 62 to 64 .

In some countries the gap between the statutory and actual retirement ages is striking. Poland is the most dramatic example: a median male worker retires 8 years before reaching the official retirement age of 65 , and as many as eight out of ten Poles retire before reaching

\footnotetext{
${ }^{34}$ The effect of the minimum wage on youth employment was not studied in the sample of EU8+2 countries; therefore one cannot draw firm conclusions. Nonetheless it is unlikely that the minimum wage regulations are responsible for such a low youth employment rate in the region.

${ }^{35}$ According to international standards, working age is defined as $15-64$ for both men and women.
} 
65. In Croatia, Hungary and Slovenia the gap is from 2.5 to 3.5 years. Interestingly, in Estonia and Lithuania men tend to retire after reaching the official retirement age. This is likely related to tight labor markets in those countries with attendant labor shortages. Hence, those two Baltic countries lead the way and provide an example of how to deal with labor shortages by mobilizing labor supply of older workers.

Country variation within the region in the median retirement age of men is considerable (Chart 18, Panel A). The range is from 57 years in Poland, to 65 in Estonia. Paradoxically, the official retirement age in Estonia is two years lower than in Poland. This suggests that the way to raise labor force participation of older workers is not only through raising the official retirement age but also - and perhaps more importantly - through creating economic incentives for postponing retirement and encouraging economic activity. ${ }^{36}$

Chart 18. Official and Actual (Median) Retirement Age in EU8+2, 2005

Panel A - Men

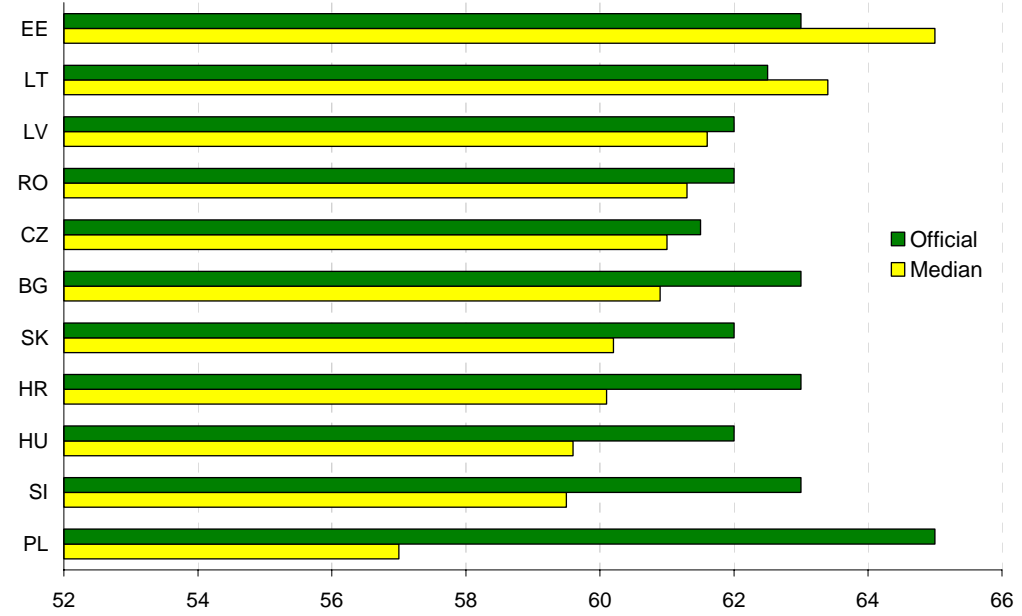

${ }^{36}$ The Baltic States - where the median retirement age is the highest in EU $8+2$ - discourage early retirement by reducing pension benefit, and encourage deferred retirement through higher accrual factors. For example, in Estonia pension benefit is increased by 0.9 percent for every month after the statutory retirement age and in Lithuania by 8 percent for each year. At the same time, in both countries pension benefit is reduced by 0.4 percent for every month of retirement before the official age. 
Panel B - Women

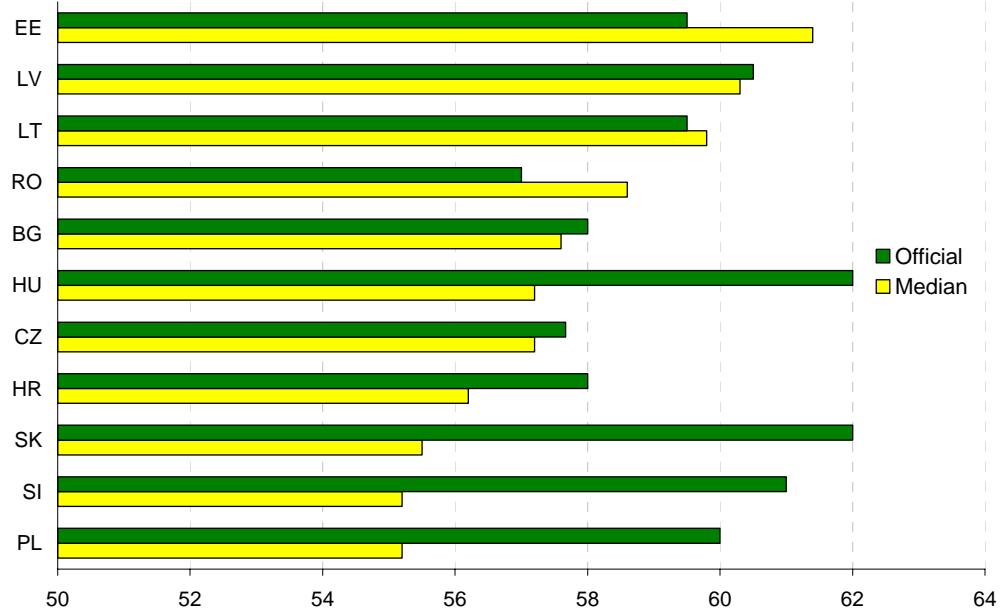

Source: Romans (2007) on median retirement age; MiSSOC Database, National Strategy Report on Adequate and Sustainable Pensions (2006) on official retirement age; Bank staff calculations

The pattern of early retirement of women is even more pronounced than that of men (Chart 18, Panel B). The official retirement age of women is uniformly lower (by 2 to 5 years) than that of men, with the exception of Hungary and Slovakia, where it was equalized. The actual retirement age is lower still: the average of EU8+2 median retirement ages for women is below 58 years. Again, the actual retirement age of women is the highest in the Baltic States (61 in Estonia), and the lowest in Poland (55).

Chart 19 demonstrates a close relationship between the average age at which workers exit the labor force and the employment rate of older workers. This provides strong support for the argument that the primary cause of the low employment rate among older workers of productive age in EU8+2 is the prevalence of early retirement. Accordingly, the main way to increase the employment rate among older workers is to reform pension systems so as to discourage workers from retiring before reaching the working age limit.

In many EU8+2 countries disability schemes provide additional options for early retirement from the labor force. For example, in the early 2000s

Chart 19. Average exit age from labor force and employment rate among older workers (55-64), EEA, 2005

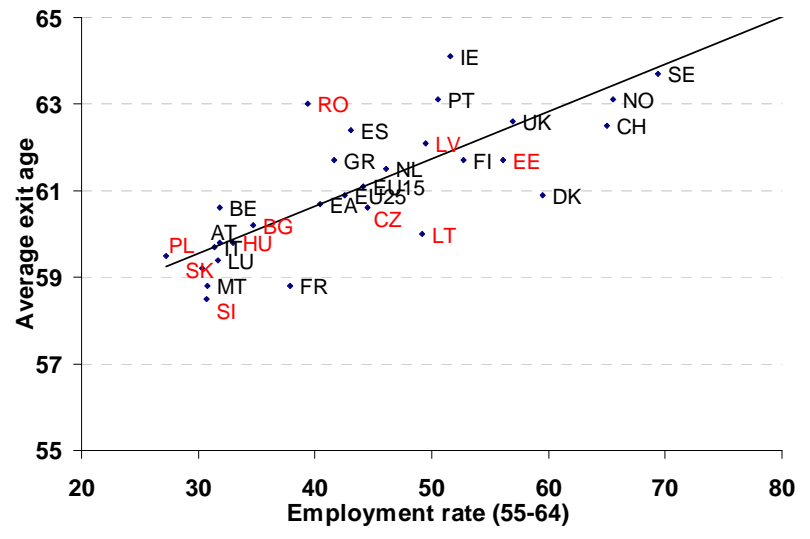

Source: Eurostat, Bank staff calculations

Poland had one of the highest percentages of working age persons receiving a disability pension in Europe. Since then it managed to the reduce the number of disability pension recipients from over 9 per 100 persons of working age in 2000 to less than 6 in 2006 by tightening the system. Still, disability pension recipients account for some 30 percent of all economically inactive aged 55-64 in Poland. In Estonia and Lithuania the share is even higher. The share in other countries is smaller but still substantial, meaning that the relatively easy access to disability pensions is an additional factor contributing to labor force withdrawal of older workers in EU8+2 (Chart 20). 
Chart 20. Share of inactive due to illness and disability (55-64), 2006

Disability is a frequent cause of inactivity among older workers in EU8+2

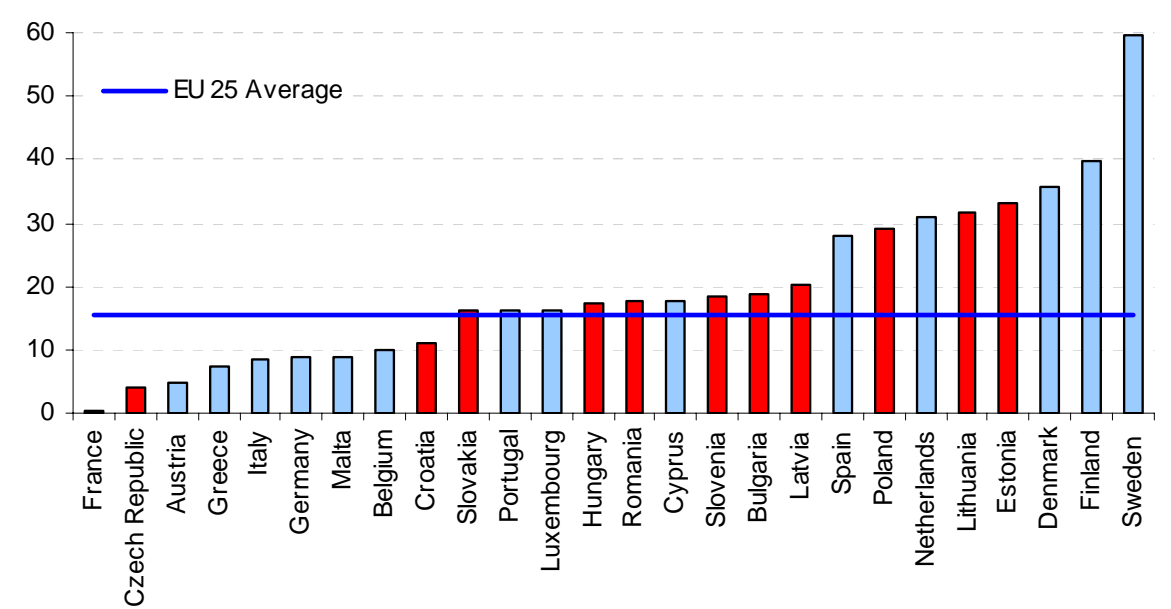

Source: Eurostat

Notes: EU15- UK and IE not included

\section{Skill Shortages: An Emerging Challenge}

Labor market tightening and the strong growth in labor demand in EU8+2 in the recent years have given rise to labor and skill shortages. Skill shortages have become one of the top business concerns, and are increasingly seen as a constraint to future firm growth. Labor shortages are most prevalent in the booming construction industry, but also manufacturing and increasingly other industries. It is skilled workers for whom demand has increased the most and who are in short supply. ${ }^{37}$ Out-migration to EU15 countries has contributed to labor shortages and to wage pressures. This section attempts to document these developments.

The lack of skilled labor has become companies' top concern. On average in the EU $8+3$ countries every third company found that lack of skilled workers is an important obstacle to business growth, especially in expanding companies. In some countries, notably Latvia, Lithuania and the Czech Republic skill shortages were already serious concern in 2005 (Chart 21). Survey data and anecdotal evidence suggest that these tendencies deepened in 2006 and 2007 and the lack of skilled workers is becoming a top concern for enterprises (Box 2).

\footnotetext{
${ }^{37}$ Workers with secondary technical/ vocational education or training.
} 


\section{Chart 21. Percentage of Firms that report worker skills as an important ${ }^{\text {a) }}$}

obstacle to firm operation and growth, 2005

Worker skills are an important obstacle to firm operation and growth, especially for expanding firms Panel A

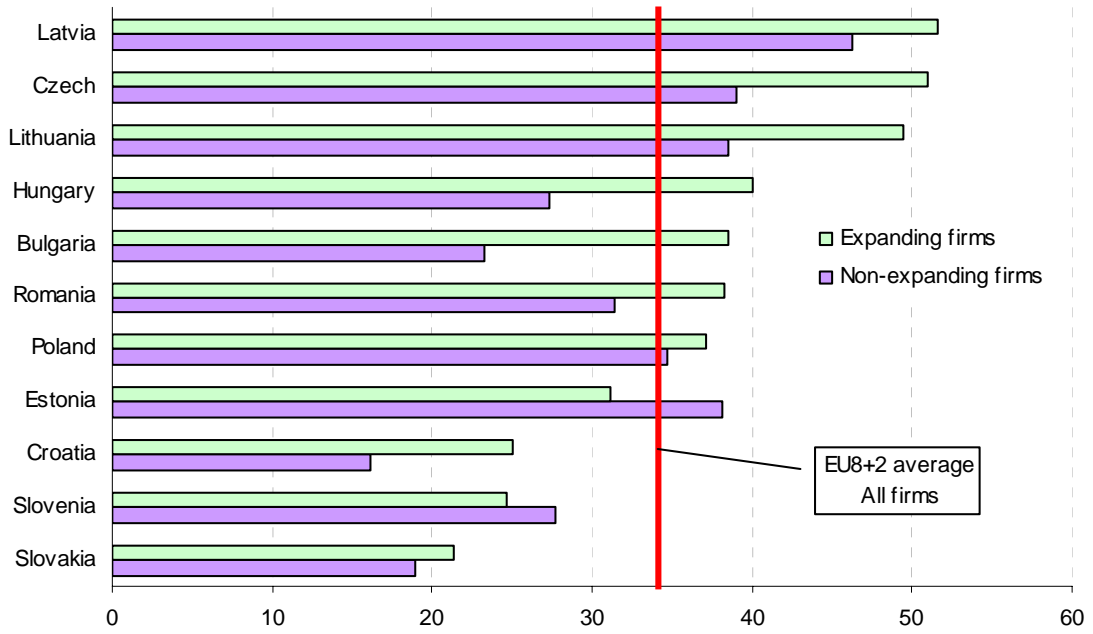

Panel B

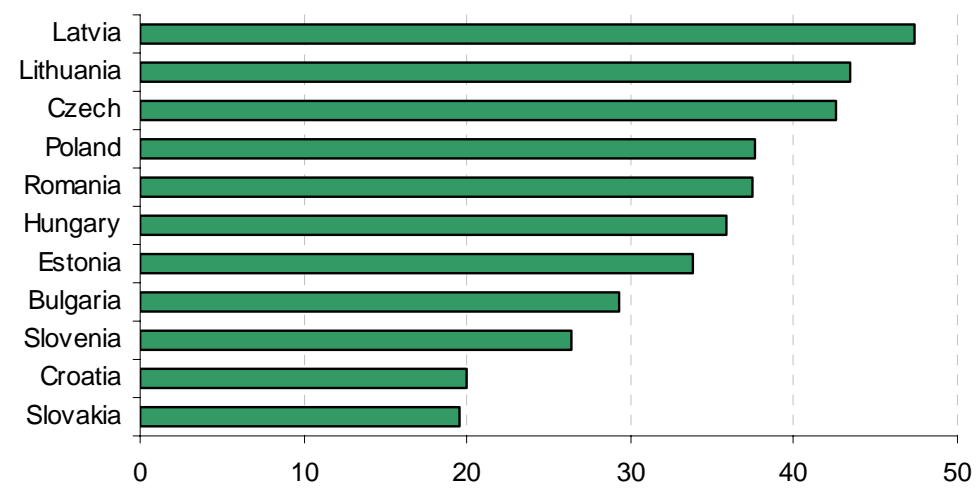

a) Severe or moderate.

Source: Source: EBRD-World Bank BEEPS 2005; Bank staff calculations

Notes: Firms are categorized as "expanding" if they increased employment over the last 36 months.

Otherwise they are categorized as "declining".

Countries that are particularly affected by skill shortages are Latvia, Lithuania, the Czech Republic, Poland (see Box 2), Romania and Hungary. In those countries skills of available workers were seen as an important obstacle to firm activity by 35 to 45 percent of all firms. ${ }^{38}$ Expanding firms - those that increased employment - were particularly vulnerable to skill shortages. For example, in the Czech Republic skill shortages were reported by over 50 percent of expanding firms and less than 40 percent of declining firms. This indicates that a firm's further growth hinges on the availability of skilled workers and that skill shortages are likely to become a binding constraint to firm expansion in EU8+2 countries.

\section{Box 2. Difficulties with recruiting workers in Poland}

Enterprise survey data show that the difficulty with hiring workers with required skills has

${ }^{38}$ Data refer to 2005; ince then skills shortages have become even more pronounced, as the Polish example clearly demonstrates (see Box 2) 
significantly increased in Poland in the last two years. Since end 2005 skill shortages have moved from 13th position in the ranking of obstacles to growth to become firms' top concern in 2007 (reported by 13 percent of enterprises). The most affected is the construction sector (34\% of enterprises), but also increasingly manufacturing (15\%) and trade (7\%). The companies have problems not only with hiring new staff but also with retaining workers.

\section{Chart B2.1. Employers perceive increasing hiring difficulties as the main obstacle to growth...}

Enterprises reporting hiring difficulties in an open survey on key obstacles to growth (in \%) and the rank of this obstacle

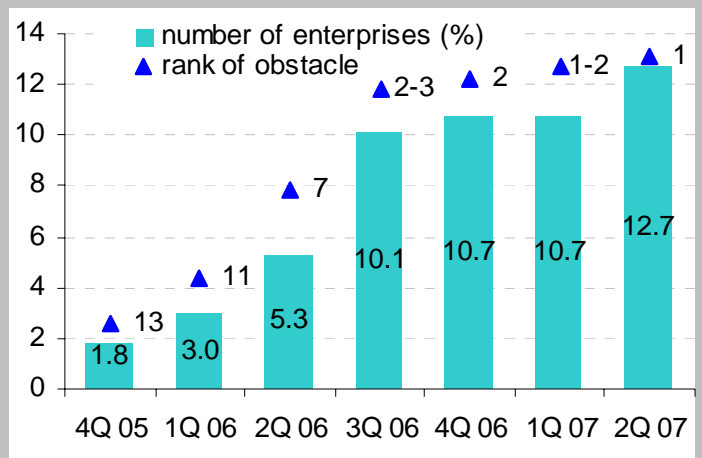

Source: NBP (2007).

A survey of hiring difficulties conducted by the National Bank of Poland revealed that in 2007 as many as $60 \%$ of enterprises reported problems with recruiting workers, up from $42 \%$ in 2006 . Firms have particular problem with finding skilled workers ( $55 \%$ of firms). However, increasingly they also report problems with hiring unskilled workers ( $24 \%$ of firms)

\section{Chart B2.3. Hiring difficulties are reported by an increasing number of companies...}

Enterprises reporting hiring difficulties (in a direct question on staff shortages), \%

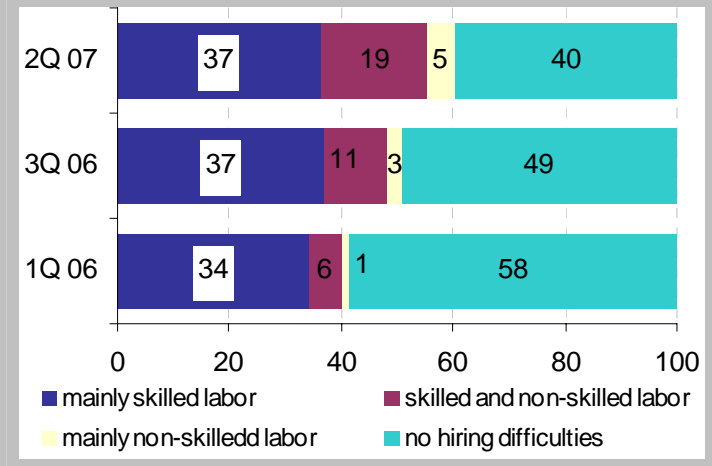

Source: NBP (2007).

\section{Chart B2.2. ... in particular in construction, but} also in manufacturing and trade

Enterprises reporting hiring difficulties in an open survey in 2Q 2007, \% by sector

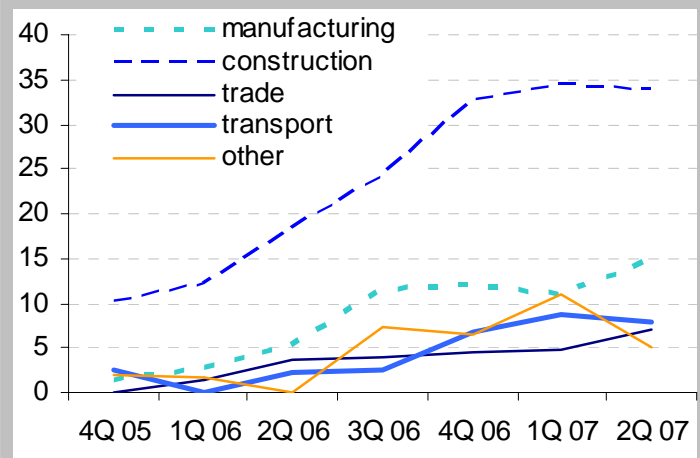

Source: NBP (2007).
Chart B2.4. ... already more than a half companies in construction, manufacturing and services

Enterprises reporting hiring difficulties (in a direct question on staff shortages) in 2Q 2007, \% by sector

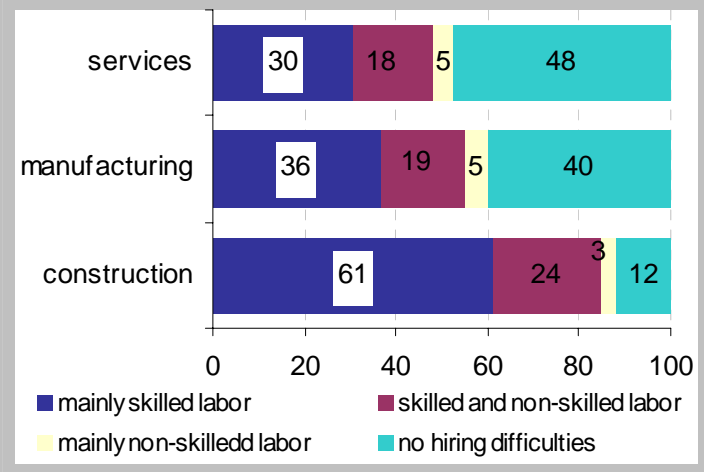

Source: NBP (2007). 
The most affected is the construction industry, where hiring problems are reported by close to 90 percent of firms. Construction firms mostly have difficulties with recruiting skilled (85\%) but also with non-skilled workers (27\%). But other industries experience skill shortages, too. In manufacturing and in services, over 60 percent of firms find it difficult to find workers with required skills. In trade the proportion is smaller, but still substantial (50 percent).

Source: National Bank of Poland 2007.

Hiring a worker with required skills takes a long time, particularly in the case of skilled workers. Time needed to hire a qualified worker is significant, especially at higher skill levels (Chart 22). However, the severity of skill shortages varies significantly across countries (Chart 23).

\section{Chart 22. Time needed to fill a vacancy (in weeks) \\ Filling a vacancy is time consuming...}

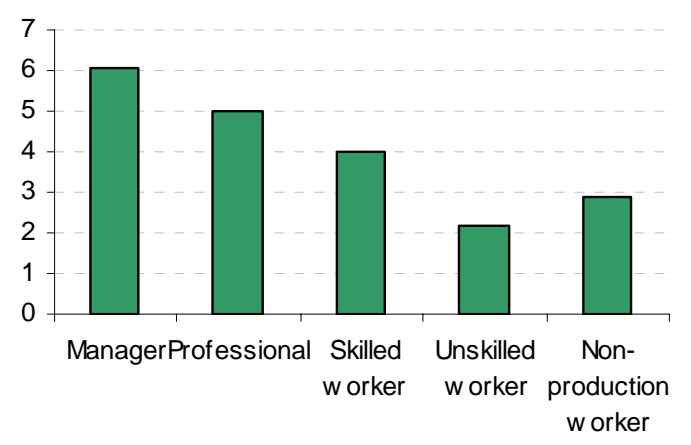

Source: EBRD-World Bank BEEPS 2005; Bank staff calculations

Notes: Data refer to EU8+2 countries and Croatia Non-production worker: e.g. administrative or sales worker.

\section{Chart 23 Time needed to fill a vacancy for a skilled worker (in weeks) \\ ... and varies across countries}

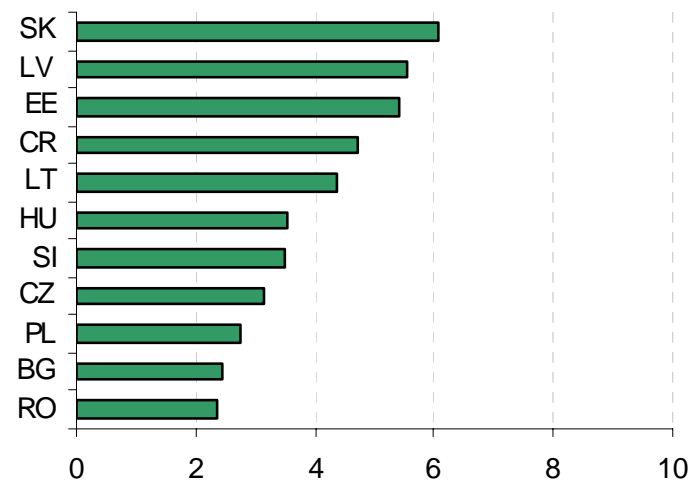

Source: EBRD-World Bank BEEPS 2005; Bank staff calculations

In some countries further evidence of growing labor and skills shortages comes from increasing vacancy rates. In Latvia, Lithuania and Poland vacancy rates have been growing since 2005 and are particularly high in construction. In Lithuania and Latvia the manufacturing sector also seems to be affected with vacancy rates almost tripling since 2005. A slight upward trend is visible also in trade services.

Chart 24. Vacancy rates by sector in selected EU8+3 countries Labor shortages are evidenced in growing vacancy rates
Czech Republic
Latvia
Lithuania
Poland*

\section{Manufacturing}
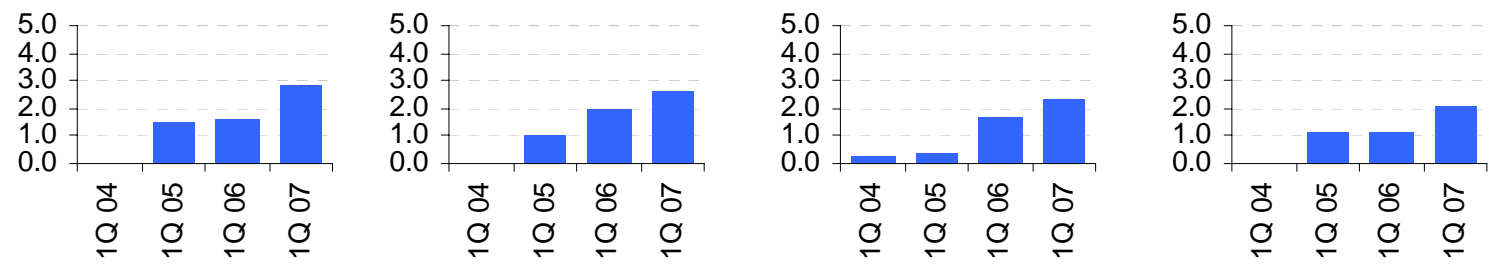


\section{Construction}
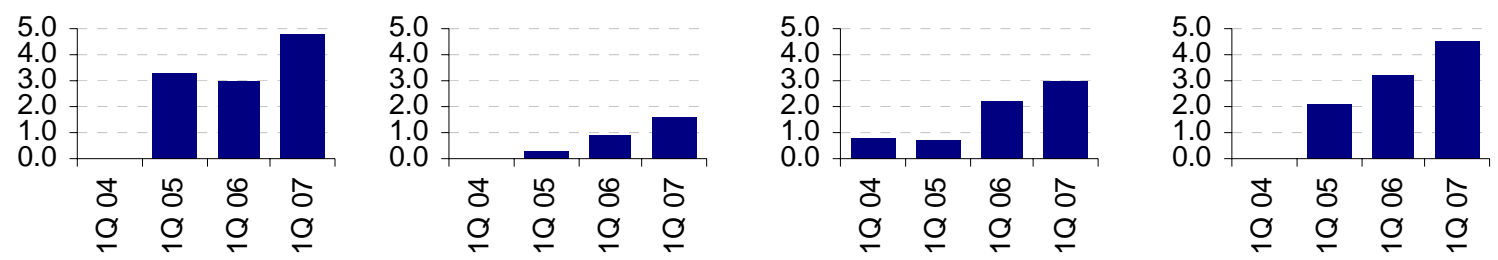

Trade
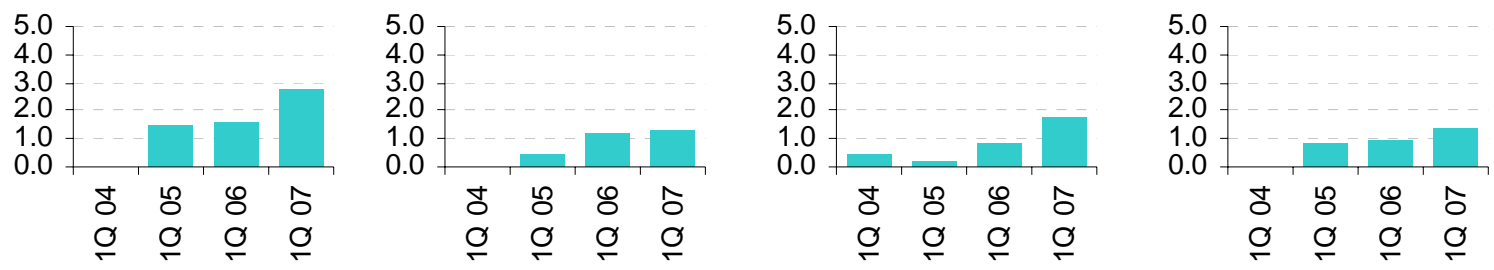

* in enterprises with 10 or more employees

Source: Eurostat; Bank staff calculations

Labor shortages are also translating into mounting wage pressures, with wages growing in excess of productivity gains. Wages are accelerating on the back of increased demand and skill shortages. In a number of sectors, notably in construction, the salary increases exceed growth of labor productivity, translating into higher unit labor costs.

\section{Chart 25. Unit labor costs in construction, yoy \%}

Chart 26. Unit labor cost in industry, yoy

Wages growing in excess of productivity are driving upward trend in ULC in construction...

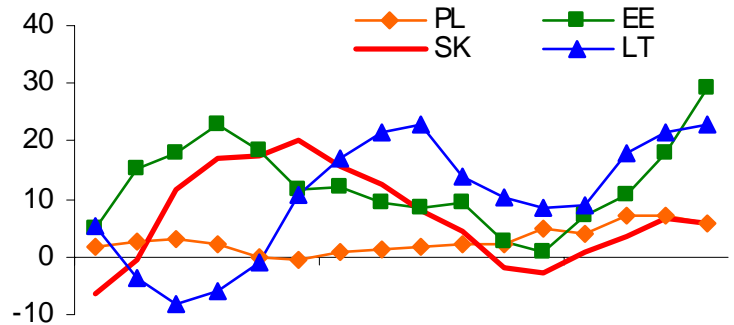

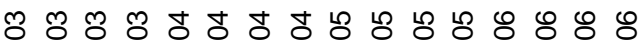

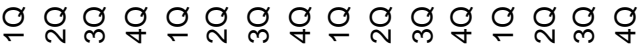

Source: Eurostat, CSOs, Bank staff calculations

\section{$\%$}

... but upward trends are also visible in industry

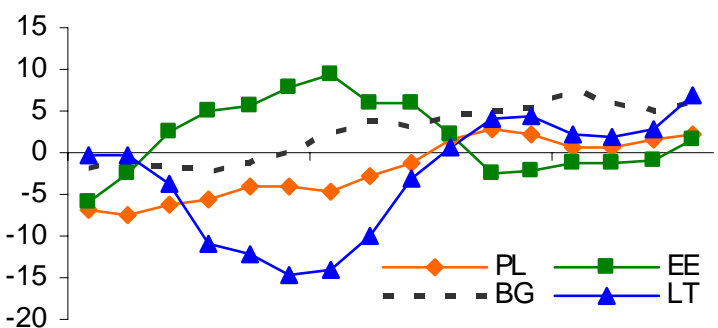

ஜ ஜ ஜ ஜ ஜ

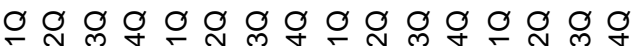

Source: Eurostat, CSOs, Bank staff calculations

The unemployed often lack skills required by the employers and cannot fill available job vacancies. Chart 27 shows that the number of workers with basic skills (less than upper secondary education) is higher than the number of jobs requiring only basic skills. ${ }^{39}$ This implies that many of the unemployed, those with low skills, will not be able to find employment even if there are more job vacancies, because they lack skills required in the newly crated jobs. There is thus an excess supply of low-skilled labor in the region, pointing to a strong structural component of unemployment (see section II). The "excess supply" of unskilled labor seems to be particularly pronounced in Bulgaria, the Czech Republic, Hungary and Slovakia. Addressing structural unemployment - substantial skill gaps and mismatches prevailing in most EU8+2 countries - poses a considerable policy challenge.

\footnotetext{
${ }^{39}$ Under the assumption that the total number of jobs equals the labor force.
} 


\section{Chart 27. "Excess Supply" of Labor by Educational \\ Attainment, 2006}

Low skills are in excess supply: the unemployed tend to have lower education than that required by employers, which limits their employment prospects

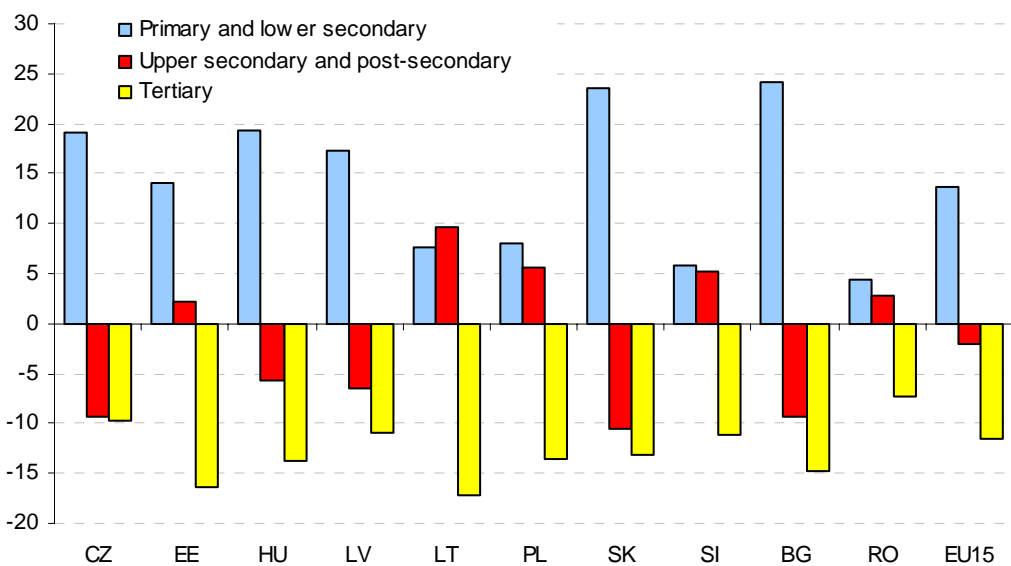

Source: Eurostat

Notes: "Excess supply" is measured as the difference between the percentage share of workers with given educational attainment in unemployment and in employment. A positive (negative) value means that that the unemployed more (less) frequently have given educational attainment than the employed. The educational structure of employment proxies that of labor demand. The educational structure of unemployment proxies that of excess labor supply. Thus the difference between those two structures shows the magnitude of the educational mismatch.

The substantial skills mismatch characteristic of most EU8+2 labor markets may mean that skills acquired under central planning became obsolete, but also may suggest that education systems are not effective in producing workers with the kinds of skills needed in modern economies. For instance, PISA results suggest that EU8+2 students perform poorly relative to the best performing old member states. ${ }^{40}$ While showing improvement since 2000, students in EU8+2 countries scored significantly below the best performing countries among the old member states. On average, students in the new member states perform closer to the poorest performing old member states - Greece, Italy, Spain, Portugal and Luxembourg - than the best performing old member states (Belgium, Finland, Ireland, the Netherlands, and the UK) (Chart 28).

\footnotetext{
${ }^{40}$ PISA stands for Program for International Student Assessment carried out by the OECD for 15-year-old students. PISA results are generally considered to provide the best available cross-country assessment of how well education systems are doing in providing skills relevant for the future.
} 


\section{Chart 28. Average scores of 15-year old students in OECD PISA Assessment, 2000 and $2003^{41}$}

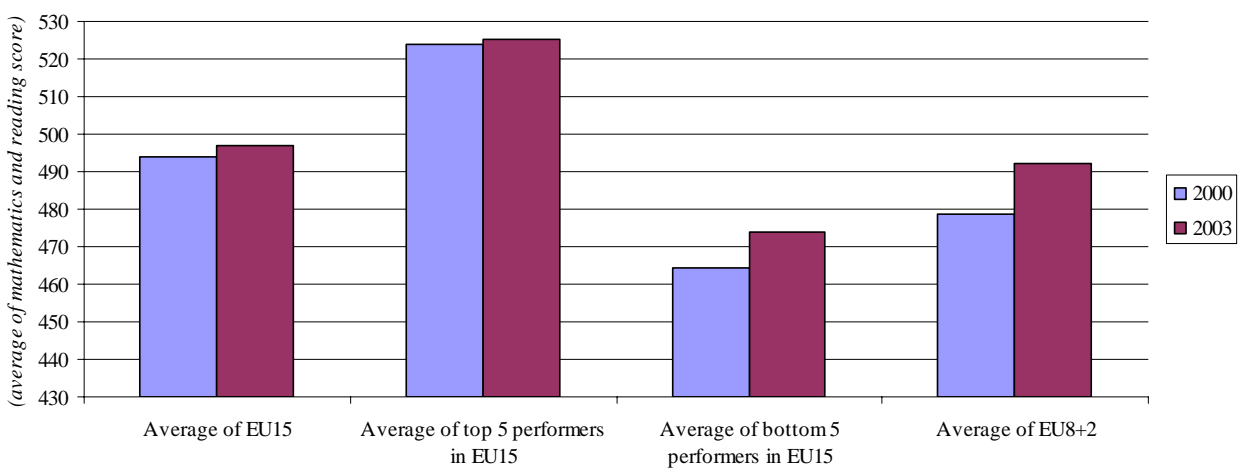

Source: PISA scores from OECD website, Bank staff calculations

To conclude, the recent strong growth in labor demand in the region has given rise to the shortages of workers with adequate skills. Skills shortages have been often amplified by outmigration associated with the opening of the EU15 labor markets. However, skill shortages often coincide with still high unemployment rates and low rates of labor force participation. This is because many of the unemployed and the inactive lack skills required in a modern economy. Human capital may thus become a binding constraint on future economic growth. This points to the need to reform the educational system so as to make it responsive to the fast changing labor market demands.

\section{Addressing Labor Shortages: Policy Options}

Labor and skill shortages have become a major labor market issue in EU8+2 economies. To address the emerging labor market challenges the countries need to increase the effective labor supply, that is supply of workers that have incentives to actively seek employment, and skills that enable them to take the newly created jobs. To do so they need to move in three directions:

- Improve labor supply incentives through reforming the social security systems and enhancing the opportunities for flexible work arrangements;

- Improve worker skills through reforming the educational systems so as to make them more responsive to labor market demands;

- Import labor with skills that are in short supply by opening labor markets to foreign workers.

The exact combination of factors causing labor shortages varies across EU8+2 countries. Accordingly, policies to address them need to be tailored to country-specific conditions. This entails identifying binding constraints to increasing effective labor supply at a country level. While in some countries reforms should focus more on improving worker skills, in others they should focus more on removing labor supply disincentives created by the social security systems or on enhancing labor market flexibility.

\section{Improving labor supply incentives}

The two target groups are youth and older workers. Measures to raise labor force participation by young workers include enhancing labor market flexibility through: promoting flexible work arrangements, such as part-time and temporary contracts; the development of temporary work agencies; and improving employment services, such as job search assistance

${ }^{41}$ Averages of EU15, EU8+2 and good and poor performers in EU15 are unweighted country averages (i.e. Germany's score is treated with the same weight as Luxembourg's score). 
and vocational counseling. Countries where the statutory minimum wage is relatively high (40 or more percent of the average wage) should consider introducing a youth sub-minimum (around 80 percent of the adult wage) to encourage employers to hire inexperienced workers of uncertain productivity. Finally, youth employment can be fostered by a targeted reduction in social security contributions. ${ }^{42}$ This would entice youth to enter the labor market by raising the take-home pay, and can also encourage employers to hire young workers by lowering their cost.

Measures to raise the labor force participation of older workers - with the aim of reaching the 60 percent employment target - include first and foremost limiting early retirement. This should be achieved by tightening eligibility conditions and lowering the benefit replacement rate in the case of retirement before reaching the statutory age. This should be coupled with strengthening financial incentives to defer retirement by increasing the accrual factor. ${ }^{43}$ Old age pensioners should also be allowed to combine work with benefit receipt (although the benefit may be reduced) after reaching the statutory retirement age. Furthermore, the official retirement age should be gradually increased to at least 65 years and equalized for men and women. The abuse of disability schemes (i.e., fraudulent claims) should be eliminated by improving governance, curbing corruption and enforcing eligibility conditions. Experience of other countries may be useful including that of Holland and Poland both of which had exceptionally high rates of utilization of disability insurance but managed to tighten the system by making appropriate changes to the rules and administrative practices. Finally, reentry of older workers to the labor market can be facilitated by the provision of well designed employment services, including options for retraining and skill upgrading.

\section{$>$ Making educational systems more responsive to changing labor market needs}

Reforms aimed at improving worker skills include (a) providing solid foundation for continuous learning to as many students as possible, (b) expanding life-long learning opportunities, and (c) linking training to trends in the industrial and occupational profile of labor demand. All this is essential for developing an adaptable labor force and preparing workers for the world of increasing occupational mobility caused by the rapid technological progress.

Providing a solid foundation for future learning is important for two reasons. This broad category includes improving access to and the quality of education. First, with some foresight and planning, new graduates can bring skills which are in short supply to the labor market. Second, and perhaps more important in the context of EU8+2's aging (and, in some cases, shrinking) population, a solid educational foundation has been shown to be a key determinant of the extent to which workers continue to upgrade their skills throughout their working careers. To accomplish these goals the EU $8+2$ countries must address two problems First, many of them continue to have an early and clear separation of students between general and narrow vocational education with few possibilities for switching between the two types at a later stage. This practice is continuing in EU8+2 while the global trend is to introduce secondary education curriculum which prioritize skills and competencies that go beyond, and cut across, the traditional general-vocational divide. ${ }^{44}$ Second, available data suggest that the quality of education is lagging behind most of the older EU member states, especially with regarding to the types of skills that are most needed in jobs for which demand is growing the fastest.

Encouraging life long learning is critical in a world of rapid technological change, where specific vocational qualifications (as opposed to general literacy and numeracy skills)

\footnotetext{
${ }^{42}$ Such schemes were introduced, for example, in Belgium, France and the Netherlands (see OECD 2003)

43 The rate at which pension benefit builds up with the length of service.

${ }^{44}$ See, for instance, World Bank 2005: “Expanding Opportunities and Building Competencies for Young People - A New Agenda for Secondary Education"
} 
acquired at school fast become obsolete. This is coupled with a fast pace of generation of new knowledge, which workers need to master to successfully perform their jobs. Furthermore, the fast rate of job reallocation, characteristic of dynamic modern economies, compels workers to move frequently from old to new jobs, which often require different skills. Finally, technological progress tends to be biased towards higher skills, which means that workers need to be able to upgrade their skills to meet the changing job requirements.

EU8 +2 countries are falling behind when it comes to lifelong learning (with the noticeable exception of Slovenia). In the best performing countries in the EU, more than 25 percent of adults participate in some form of education and training. By comparison, on average, only 5 percent of adults participated in such learning in EU8+2. To accelerate income convergence, not only this gap should be narrowed, but EU8+2 should be leading the way.

Improving the quality of learning and expanding life long learning is costly. Ways to avoid large increases in the education budget include: i) transferring more of the cost of postsecondary education, including lifelong learning, to beneficiaries. This would involve shifting part of the fiscal burden to workers as well as employers by allowing training institutions to charge fees; and ii) encouraging the growth of private institutions. In the education sphere, private entrepreneurs are unlikely to participate if no clear policies are articulated for fees and there is uncertainty regarding the possible public provision of similar (and cheaper) services. However, within a well-specified framework (and possible with financial incentives to start up), policy makers can encourage private institutions to provide training. This shifts the risks and difficulties associated with determining labor market demands to the private sector which is usually better equipped to provide just-in-time vocational training.

Linking training provision to trends in industrial and occupational profile of labor demand. This is critical for labor market relevance of training programs and training institutions. Especially in the case of vocational education and training it should be the employer who is considered as the primary customer. One way of achieving this is through actively involving employers in curriculum development. Another and complementary method is to utilize information on the current and projected trends in labor demand. This in turn assumes the development of good labor market information systems, which provide data on changes in employment, wages and job vacancies by industry and occupation.

On-the-job training can play an important role in improving the supply of workers with relevant skills. On the job training provided through the private sector can ensure help to provide certain needed skills in a more timely and cost effective fashion than can be done through the public system. However, there is not a long history of the such training programs among the EU8+2 in part because shortages are relatively new and skilled workers were readily available in the earlier structural reform stage of transition when there was significant labor surplus, and because many newer firms are too small to develop programs. Tax incentives and support using EU funds may be effective means of stimulating such initiatives.

\section{$>$ Opening labor markets to foreign workers}

This is a fast way of dealing with labor and skills shortages. There are signs that some of EU8+2 countries are increasingly willing to adopt this strategy. For example, in the face of labor shortages, Poland has recently removed some bureaucratic barriers to employment of foreign workers, resulting in significant growth in immigrants employment. However, changes are partial and restrictions on foreigners' employment still remain.

None of the EU8+2 labor markets can be considered fully open to foreign workers. This is not without reason. Opening the domestic labor market to foreign workers is politically a highly sensitive issue. Trade unions usually strongly oppose such moves arguing that foreign workers take the jobs from the unemployed, that they will "unfairly" compete with domestic workers and will bid wages down. Furthermore, a large scale inflow of foreign labor may fuel social tensions and weaken social cohesion. For all these reasons countries tend to adopt a cautious approach to the opening of their labor markets. A delicate balance needs to be struck between 
the labor market needs and the society's capacity to absorb migrant workers. However, the experience of countries that did recently open their labor markets to EU8+2 workers - such as Ireland, Sweden and the UK - indicates that overall the balance is positive. Opening the market to migrant labor helps to address skills shortages and thus contributes to economic growth and economic prosperity (World Bank 2006).

Some workers who have left the EU8+2 to work elsewhere in Europe may over time be encouraged to return. If wages rise, emigration rates may taper off easing supply constraints. However, while this income convergence process is desirable it depends on increases in productivity that will make such wage increases sustainable.

\section{References}

Betcherman, Gordon, Karina Olivas and Amit Dar (2004), "Impacts of Active Labor Market Programs: New Evidence from Evaluations with Particular Attention to Developing and Transition Economies", Social Protection Discussion Paper Series, No. 0402, World Bank, Washington, DC.

Boone, J an and J an C. van Ours (2004), "Effective Active Labor Market Policies", IZA Discussion Paper No. 1335.

National Bank of Poland.2007. Informacja o kondycji sektora przedsiebiorstw ze szczegolnym uwzglednieniem stanu koniunktury w III kw 2007, July.

Neumark, D. and Wascher, W. (2007), "Minimum Wages and Employment", IZA Discussion Paper No. 2570

OECD (2003), Employment Outlook, Paris.

OECD (2006), Employment Outlook, Paris.

Romans, Fabrice (2007), "The transition of women and men from work to retirement", Statistics in focus, Luxembourg: Eurostat.

Rutkowski, Jan (2003a), “Does Strict Employment Protection Legislation Discourage Job Creation? Evidence from Croatia", Policy Research Working Paper3104, World Bank, Washington, DC.

Rutkowski, Jan (2003b), "Minimum Wage: Curse or Cure?", Photocopy, World Bank, Washington, DC.

Rutkowski, J an (2004), "Labor Market Interventions during the Transition in ECA", SPectrum (Summer), World Bank, Washington, DC.

Rutkowski, J an and Mateusz Walewski (2007), "Taxation of Labor", in. Ch. Grey, T. Lane and A. Varoudakis (eds.), Fiscal Policy and Economic Growth: Lessons for Eastern Europe and Central Asia. Washington, DC: World Bank.

World Bank (2002), Transition: The First Ten Years. Analysis and Lessons from Eastern Europe and the Former Soviet Union, Washington, DC.

World Bank (2005), Enhancing J ob Opportunities: Eastern Europe and the Former Soviet Union. Washington, DC: World Bank.

World Bank (2006), "Labor Migration from the New EU Member States", Quarterly Economic Report, Special Topic (September) 